\title{
The prevalence of Chlamydia trachomatis infection in Australia: a systematic review and meta-analysis
}

Dyani Lewis ${ }^{1}$, Danielle C Newton ${ }^{1}$, Rebecca J Guy ${ }^{2}$, Hammad Ali ${ }^{2}$, Marcus Y Chen ${ }^{1,3}$, Christopher K Fairley ${ }^{1,3}$ and Jane S Hocking ${ }^{1 *}$

\begin{abstract}
Background: Chlamydia trachomatis is a common sexually transmitted infection in Australia. This report aims to measure the burden of chlamydia infection by systematically reviewing reports on prevalence in Australian populations.

Methods: Electronic databases and conference websites were searched from 1997-2011 using the terms 'Chlamydia trachomatis' OR 'chlamydia' AND 'prevalence' OR 'epidemiology' AND 'Australia'. Reference lists were checked and researchers contacted for additional literature. Studies were categorised by setting and participants, and meta-analysis conducted to determine pooled prevalence estimates for each category.

Results: Seventy-six studies met the inclusion criteria for the review. There was a high level of heterogeneity between studies; however, there was a trend towards higher chlamydia prevalence in younger populations, Indigenous Australians, and those attending sexual health centres. In community or general practice settings, pooled prevalence for women $<25$ years in studies conducted post-2005 was 5.0\% (95\% Cl: 3.1, 6.9; five studies), and for men $<30$ years over the entire review period was 3.9\% (95\% Cl: 2.7, 5.1; six studies). For young Australians aged $<25$ years attending sexual health, family planning or youth clinics, estimated prevalence was $6.2 \%$ (95\% Cl: 5.1, 7.4; 10 studies) for women and 10.2\% (95\% Cl: 9.5, 10.9; five studies) for men. Other key findings include pooled prevalence estimates of $22.1 \%$ (95\% Cl: 19.0, 25.3; three studies) for Indigenous women $<25$ years, $14.6 \%$ (95\% Cl: $11.5,17.8$; three studies) for Indigenous men $<25$ years, and $5.6 \%$ (95\% Cl: 4.8, 6.3; 11 studies) for rectal infection in men who have sex with men. Several studies failed to report basic demographic details such as sex and age, and were therefore excluded from the analysis.
\end{abstract}

Conclusions: Chlamydia trachomatis infections are a significant health burden in Australia; however, accurate estimation of chlamydia prevalence in Australian sub-populations is limited by heterogeneity within surveyed populations, and variations in sampling methodologies and data reporting. There is a need for more large, population-based studies and prospective cohort studies to compliment mandatory notification data.

Keywords: Chlamydia, Meta-analysis, Prevalence, Systematic review

\footnotetext{
*Correspondence: j.hocking@unimelb.edu.au

${ }^{1}$ School of Population Health, University of Melbourne, Carlton, Victoria, Australia

Full list of author information is available at the end of the article
}

\section{Biomed Central}

(c) 2012 Lewis et al.; licensee BioMed Central Ltd. This is an Open Access article distributed under the terms of the Creative Commons Attribution License (http://creativecommons.org/licenses/by/2.0), which permits unrestricted use, distribution, and reproduction in any medium, provided the original work is properly cited. 


\section{Background}

Chlamydia trachomatis (here after referred to as chlamydia) is the most commonly diagnosed bacterial sexually transmitted infection (STI) in Australia [1,2]. In women, chlamydia can lead to serious and costly health consequences, particularly if the infection ascends from the endocervix to the upper genital tract and causes pelvic inflammatory disease (PID), which may result in fallopian tube scarring, ectopic pregnancy, tubal infertility and chronic pelvic pain [3-6]. Chlamydia also causes epididymo-orchitis in men $[7,8]$ and can act as a co-factor in increasing the risk of HIV transmission in both men and women [9].

Genital chlamydial infection became a notifiable disease in 1991 in all Australian States and Territories except for NSW, which introduced mandatory notification in 1997 [1]. Notification rates have been steadily rising over the past decade [2], with rates highest among young people. Chlamydia notification rates are highest in the Northern Territory [2], which records high rates among Indigenous Australians [10]. Given that chlamydia is asymptomatic in up to $90 \%$ of infections, testing rates remain low (less than $10 \%$ in the younger age groups) [11], and re-infections are common, notification data greatly underestimate the true burden of infection. It is therefore important to gather high quality, region-specific epidemiological data to estimate the prevalence of chlamydia in Australian populations. A review published in 2005 reported an overall prevalence of chlamydia of $4.6 \%$ (95\%CI: $4.4 \%, 4.8 \%$ ) [12]; however, there has been considerable further chlamydia epidemiological research conducted in Australia since then. This review examines the available data on the prevalence of chlamydia across Australia and provides an up-to-date picture of the burden of chlamydia in Australian communities. This information will help to inform future clinical practice and screening policies.

\section{Methods}

\section{Review strategy}

The electronic bibliographic database Medline was searched for English-language articles published between 1997 and July 2011. Reference lists of selected studies were also checked for other potentially relevant studies. Proceedings of the Australian Sexual Health Conference were also reviewed to identify potential unpublished studies. The PRISMA statement for preferred reporting of systematic reviews and meta-analyses was used as a guide to conducting the review and analysis [13].

The following search terms were used: (Chlamydia trachomatis OR chlamydia) AND (prevalence OR epidemiology) AND Australia.
The studies were reviewed and information extracted by two authors independently; disagreements were resolved by discussion and consensus. Criteria for inclusion were:

- Individuals were tested during the review period, 1997 to July 2011;

- The study presented the number of infections and the total number of individuals tested;

- Nucleic acid amplification tests (NAAT) were used.

Studies were excluded for the following reasons:

- The study described self-reported STI diagnoses;

- Tests other the NAAT were used [14];

- The type of test was not specified and testing was performed prior to 2000 .

Studies conducted partially within the review period were included if year-by-year data was presented, or if the time was substantially within the review period and NAAT testing was used throughout.

Variables extracted from each study included geographical location, year of the study, setting, participants, specimen type, gender, number of participants and number testing positive. Where possible, the age (mean or range), participation rates, and age- and sex-specific prevalence data were also extracted. For studies that did not report them, 95\% confidence intervals $(\mathrm{CI})$ were calculated using exact methods in STATA 11 (StataCorp, College Station, TX, USA).

Results were classified by setting and participants, with studies grouped into the following categories: general practice (GP) or community-based populations; clients of sexual health, and family planning centres, youth centres, and other medical clinics; pregnant women; Indigenous Australians; men who have sex with men (MSM); and high-risk populations. Chlamydia positivity (number testing positive divided by total number tested) was used as a surrogate measure of chlamydia prevalence and on this basis, the term 'prevalence' will be used throughout this review.

\section{Meta-analysis}

Where appropriate and where data was available, female and male data were pooled separately for meta-analysis (STATA 11; StataCorp, College Station, TX, USA). Studies reporting combined prevalence data for male and female participants were excluded from meta-analysis. The $\mathrm{I}^{2}$ test was used to estimate the proportion of total variability in point estimates attributed to heterogeneity other than that due to chance. Data were pooled according to the level of between-study heterogeneity, using the following strategy [15]:

- $\mathrm{I}^{2}<25 \%$, fixed effects meta-analysis to estimate the common prevalence $(95 \% \mathrm{CI})$, assuming that all or most between-study variability is due to chance; 
- $\mathrm{I}^{2} 25-75 \%$, random effects meta-analysis to estimate the average prevalence $(95 \% \mathrm{CI})$;

- $\mathrm{I}^{2}>75 \%$, heterogeneity too great for summary estimate to be calculated.

Possible reasons for heterogeneity were explored by stratifying results by study setting.

\section{Results}

A total of 76 studies, described in 78 published articles and six conference abstracts, from 129 articles and 48 abstracts fit the inclusion criteria (Figure 1; Table 1; Additional files 1, 2, 3, 4, and 5). The majority of studies (49 of 76) estimated chlamydia prevalence through crosssectional surveys, with sample sizes of between 44 and 2817 participants (median 346). There were also 19 clinical audits (median sample size 505; range 8026,097), three cohort studies (median 457; range 4561642), three sentinel surveillance reports (median 30,516; range 3551-69,927), and two randomised controlled trials (RCTs; mean 1218; range 843-1593).

Where both male and female participants were included (30 studies), a substantial portion (16 studies) did not report these data separately, or failed to report by sex for some categories. These data were excluded from further meta-analysis.

Where reported, the most commonly utilised sample was first-void urine for both men and women; however, other samples included urethral, rectal and pharyngeal swabs for men; and endocervical swabs, self-obtained lower vaginal swabs, self-inserted tampons, and fallopian tube washings for women.

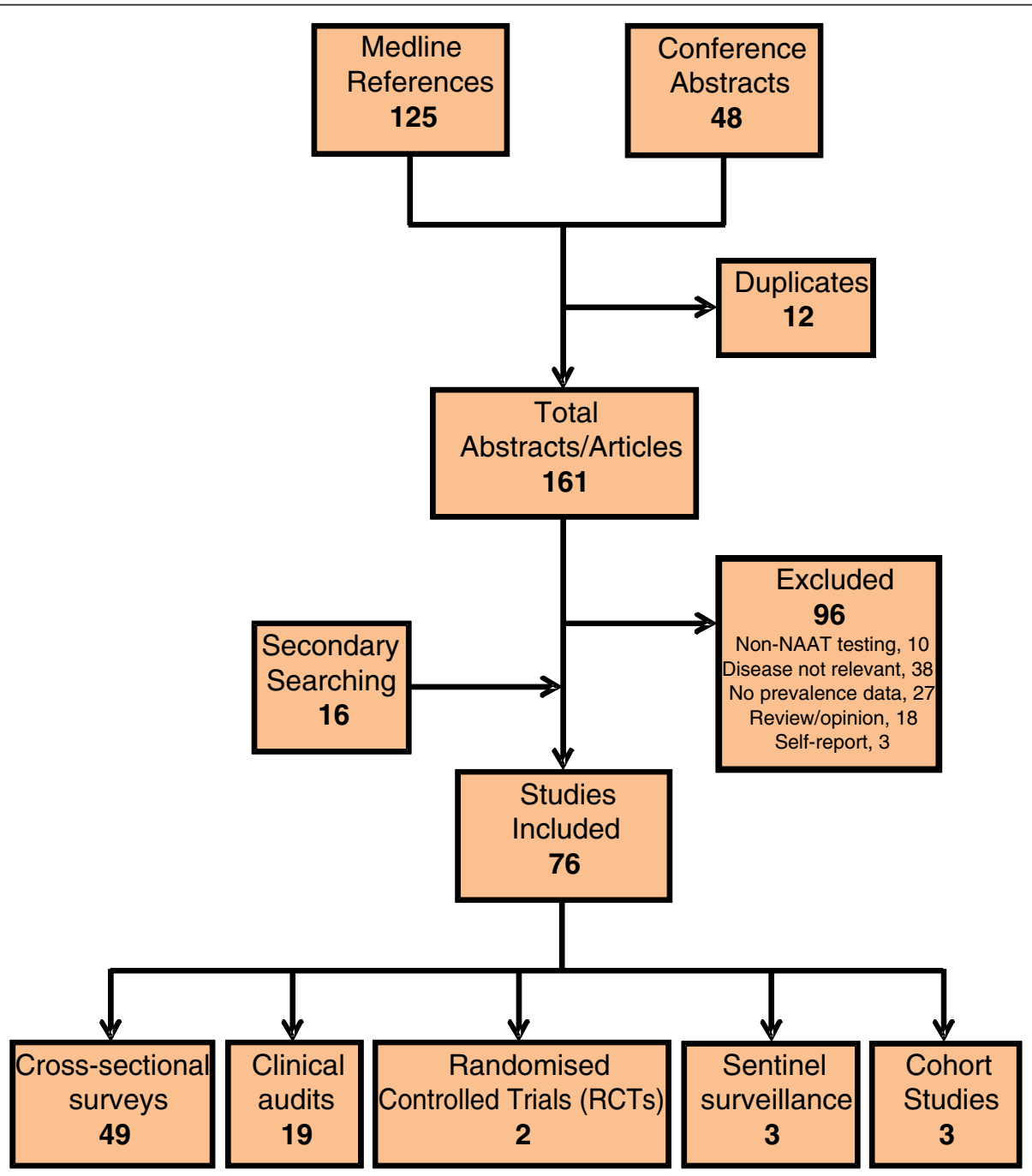

Figure 1 Systematic review of chlamydia prevalence in Australian populations. Flow chart of inclusions and exclusions from the systematic literature review. 
Table 1 Studies reporting chlamydia prevalence data, identified in general practice or community settings

\begin{tabular}{|c|c|c|c|c|c|c|c|c|c|c|c|}
\hline Study & Location & Participants & $\begin{array}{l}\text { Study } \\
\text { design }\end{array}$ & Specimen type & $\begin{array}{l}\text { Response } \\
\text { rate (\%) }\end{array}$ & Sex & $\begin{array}{l}\text { Age } \\
\text { (years) }\end{array}$ & $\begin{array}{l}\text { Study } \\
\text { period }\end{array}$ & $\begin{array}{l}\text { Tested } \\
\text { (n) }\end{array}$ & $\begin{array}{l}\text { Positive } \\
\text { (n) }\end{array}$ & $\begin{array}{l}\text { Prevalence \% } \\
(95 \% \mathrm{Cl})\end{array}$ \\
\hline \multicolumn{12}{|c|}{ General Population } \\
\hline \multirow[t]{3}{*}{ Hocking [16] } & \multirow[t]{3}{*}{ VIC (Melb) } & \multirow{3}{*}{$\begin{array}{l}\text { Women recruited from } \\
\text { the telephone directory }\end{array}$} & \multirow{3}{*}{$\begin{array}{l}\text { Cross-sectional } \\
\text { survey }\end{array}$} & \multirow[t]{3}{*}{ Urine } & \multirow[t]{3}{*}{43} & \multirow[t]{3}{*}{$\mathrm{F}$} & $18-35$ & \multirow[t]{3}{*}{$2003-2004$} & 657 & 6 & $0.9(0.3,2.0)$ \\
\hline & & & & & & & $(18-24)$ & & 135 & 5 & $3.7(1.2,8.4)$ \\
\hline & & & & & & & $(25-35)$ & & 489 & 1 & $0.2(0.0,1.1)$ \\
\hline \multicolumn{12}{|l|}{ Community } \\
\hline \multirow[t]{2}{*}{ Debattista [17] } & \multirow[t]{2}{*}{ QLD (Bris) } & \multirow{2}{*}{$\begin{array}{l}\text { University students at } \\
\text { residential colleges }\end{array}$} & \multirow{2}{*}{$\begin{array}{l}\text { Cross-sectional } \\
\text { survey }\end{array}$} & \multirow[t]{2}{*}{ Urine } & \multirow[t]{2}{*}{$30-50$} & $\mathrm{~F}$ & \multirow[t]{2}{*}{$<25$} & \multirow[t]{2}{*}{1997} & 178 & 2 & $1.1(0.1,4.0)^{*}$ \\
\hline & & & & & & M & & & 96 & 0 & $0(0.0,3.8)^{*}$ \\
\hline \multirow[t]{10}{*}{ Debattista [18] } & \multirow[t]{10}{*}{ QLD (Bris) } & \multirow[t]{10}{*}{ High school students } & \multirow{10}{*}{$\begin{array}{l}\text { Cross-sectional } \\
\text { survey }\end{array}$} & \multirow[t]{10}{*}{ Urine } & \multirow[t]{10}{*}{$30-50$} & $\mathrm{~F}$ & \multirow[t]{10}{*}{$15-18$} & 1998-2001 & 516 & 12 & $2.3(1.2,4.0)^{* *}$ \\
\hline & & & & & & M & & (1998) & 170 & 2 & $1.2(0.2,4.6)^{*}$ \\
\hline & & & & & & & & (1999) & 147 & 5 & $3.4(1.3,8.2)^{*}$ \\
\hline & & & & & & & & (2000) & 101 & 0 & $0(0.0,4.6)^{*}$ \\
\hline & & & & & & & & (2001) & 98 & 5 & $5.1(1.9,12.1)^{*}$ \\
\hline & & & & & & & & 1998-2001 & 658 & 3 & $0.5(0.1,1.3)^{* *}$ \\
\hline & & & & & & & & (1998) & 339 & 0 & $0(0.0,1.4)^{*}$ \\
\hline & & & & & & & & (1999) & 132 & 1 & $0.8(0.0,4.8)^{*}$ \\
\hline & & & & & & & & (2000) & 94 & 0 & $0(0.0,4.9)^{*}$ \\
\hline & & & & & & & & (2001) & 93 & 2 & $2.2(0.4,8.3)^{*}$ \\
\hline \multirow[t]{2}{*}{ Bowden [19] } & \multirow[t]{2}{*}{$\mathrm{ACT}$} & \multirow[t]{2}{*}{ High school students } & \multirow{2}{*}{$\begin{array}{l}\text { Cross-sectional } \\
\text { survey }\end{array}$} & F: urine/ swab & \multirow[t]{2}{*}{31} & $\mathrm{~F}$ & $15-20$ & $2002-2003$ & 273 & 2 & $0.7(0.1,2.6)$ \\
\hline & & & & M: urine & & M & & & 179 & 3 & $1.7(0.3,4.8)$ \\
\hline Davis [20] & $\mathrm{ACT}$ & $\begin{array}{l}\text { Tertiary students } \\
\text { recruited at outreach } \\
\text { screening services }\end{array}$ & $\begin{array}{l}\text { Clinical outreach } \\
\text { pilot }\end{array}$ & Urine & 29.4 & $M / F$ & $16-26$ & 2007 & 445 & 8 & $1.8(0.1,3.5)^{*}$ \\
\hline Gold [21] & $\begin{array}{l}\text { VIC } \\
\text { (rural/ regional) }\end{array}$ & $\begin{array}{l}\text { Men attending rural } \\
\text { football clubs }\end{array}$ & $\begin{array}{l}\text { Cross-sectional } \\
\text { survey }\end{array}$ & Urine & 85 & M & $16-29$ & 2006-2007 & 77 & 3 & $3.9(0.8,11.0)$ \\
\hline Wade [22] & VIC (Melb) & $\begin{array}{l}\text { Heterosexual men } \\
\text { attending sporting clubs }\end{array}$ & $\begin{array}{l}\text { Cross-sectional } \\
\text { survey }\end{array}$ & Urine & 87 & M & $16-29$ & n.r. & 47 & 4 & $8.5(2.4,20.4)^{* *}$ \\
\hline Buhrer-Skinner & QLD & Individuals attending & Cross-sectional & M: urine & n.r. & $M / F$ & $21^{\mathrm{A}}$ & 2004-2005 & 303 & 15 & $5.0(2.8,8.0)^{*}$ \\
\hline & (Iowns-Ville) & $\begin{array}{l}\text { Outreach screening } \\
\text { services set up in a } \\
\text { variety of community locations }\end{array}$ & survey & F: urine/ swab & & (M) & 25 & & 75 & 5 & $\begin{array}{l}\text { Army: } 6.7 \\
(2.2,14.9)\end{array}$ \\
\hline & & & & & & (M/F) & 21 & & 95 & 5 & $\begin{array}{l}\text { University: } 5.3 \\
(1.7,11.9)\end{array}$ \\
\hline
\end{tabular}




\begin{tabular}{|c|c|c|c|c|c|c|c|c|c|c|c|}
\hline & & & & & & $(\mathrm{M} / \mathrm{F})$ & 17 & & 68 & 0 & $\begin{array}{l}\text { High school } \\
\text { festivities: } \\
0(0,5.3)\end{array}$ \\
\hline & & & & & & $(\mathrm{M} / \mathrm{F})$ & 25 & & 65 & 5 & $\begin{array}{l}\text { Backpackers: } \\
7.7(2.5,17.0)\end{array}$ \\
\hline \multirow{2}{*}{$\begin{array}{l}\text { Kong [24]; } \\
\text { Kong [25] }\end{array}$} & \multirow{2}{*}{$\begin{array}{l}\text { VIC } \\
\text { (rural/ regional) }\end{array}$} & \multirow{2}{*}{$\begin{array}{l}\text { Young people } \\
\text { attending } \\
\text { sporting clubs }\end{array}$} & \multirow{2}{*}{$\begin{array}{l}\text { Cross-sectional } \\
\text { survey }\end{array}$} & \multirow[t]{2}{*}{ Urine } & \multirow[t]{2}{*}{$>95$} & $\mathrm{~F}$ & \multirow[t]{2}{*}{$16-29$} & \multirow[t]{2}{*}{2007} & 121 & 9 & $7.4(3.5,13.7)^{* *}$ \\
\hline & & & & & & M & & & 426 & 19 & $4.5(2.7,6.9)$ \\
\hline \multirow[t]{2}{*}{ Sacks-Davis [26] } & \multirow[t]{2}{*}{ VIC (Melb) } & \multirow{2}{*}{$\begin{array}{l}\text { Young people } \\
\text { attending a } \\
\text { music festival }\end{array}$} & \multirow{2}{*}{$\begin{array}{l}\text { Cross-sectional } \\
\text { survey }\end{array}$} & \multirow[t]{2}{*}{ Urine } & \multirow[t]{2}{*}{21} & $\mathrm{~F}$ & \multirow[t]{2}{*}{$16-29$} & \multirow[t]{2}{*}{2009} & 46 & 0 & $0(0.0,7.7)^{*}$ \\
\hline & & & & & & M & & & 21 & 1 & $4.8(0.1,23.8)^{*}$ \\
\hline \multirow[t]{6}{*}{ Davies [27] } & \multirow[t]{6}{*}{ NSW (Sydney) } & \multirow{6}{*}{$\begin{array}{l}\text { Young } \\
\text { international } \\
\text { backpackers } \\
\text { recruited } \\
\text { at hostels }\end{array}$} & \multirow{6}{*}{$\begin{array}{l}\text { Cross-sectional } \\
\text { survey }\end{array}$} & F: swab & 45.7 & $\mathrm{~F}$ & $18-30$ & \multirow[t]{6}{*}{2009} & 207 & 8 & $3.9(1.7,7.5)$ \\
\hline & & & & \multirow[t]{5}{*}{ M: urine } & \multirow[t]{5}{*}{50.2} & \multirow[t]{5}{*}{ M } & $(\leq 25)$ & & 166 & 5 & $3.0(1.0,6.9)^{*}$ \\
\hline & & & & & & & $(26-30)$ & & 41 & 3 & $7.3(1.5,19.9)^{*}$ \\
\hline & & & & & & & $18-30$ & & 225 & 7 & $3.1(1.3,6.3)$ \\
\hline & & & & & & & $(\leq 25)$ & & 164 & 6 & $3.7(1.4,7.8)^{*}$ \\
\hline & & & & & & & $(26-30)$ & & 61 & 1 & $1.6(0.4,8.8)^{*}$ \\
\hline \multicolumn{12}{|c|}{ General Practice } \\
\hline Heal [28] & QLD (Mackay) & $\begin{array}{l}\text { Young people attending } \\
\text { general practices }\end{array}$ & $\begin{array}{l}\text { Cross-sectional } \\
\text { survey }\end{array}$ & Urine & 68 & $\mathrm{~F} / \mathrm{M}$ & $18-24$ & 2001 & 443 & 17 & $3.8(2.3,6.1)^{*}$ \\
\hline Chiang [29] & VIC (rural) & $\begin{array}{l}\text { Women attending } \\
\text { general practices }\end{array}$ & $\begin{array}{l}\text { Cross-sectional } \\
\text { survey }\end{array}$ & Swab & n.d. & $\mathrm{F}$ & $15-35$ & n.r. & 67 & 9 & $13.4(6.3,24.0)^{*}$ \\
\hline Toyne [30] & ACT & $\begin{array}{l}\text { Women attending } \\
\text { general practices }\end{array}$ & $\begin{array}{l}\text { Cross-sectional } \\
\text { survey }\end{array}$ & Swab & n.d. & $\mathrm{F}$ & $17-39$ & 2002-2003 & 353 & 4 & $1.1(0.3,2.9)$ \\
\hline \multirow[t]{5}{*}{ Bowden [31] } & \multirow[t]{5}{*}{$\mathrm{ACT}$} & \multirow{5}{*}{$\begin{array}{l}\text { Women attending } \\
\text { general practices }\end{array}$} & \multirow{5}{*}{$\begin{array}{l}\text { Cluster randomised } \\
\text { controlled trial }\end{array}$} & \multirow[t]{5}{*}{ Swab/ urine } & \multirow{5}{*}{$\begin{array}{l}6.9 \text { in intervention; } \\
4.5 \text { in control }\end{array}$} & $\mathrm{F}$ & $16-39$ & 2004-2005 & 1593 & 69 & $4.3(3.4,5.5)$ \\
\hline & & & & & & & $(16-19)$ & & 196 & 10 & $5.1(2.5,9.2)$ \\
\hline & & & & & & & $(20-25)$ & & 576 & 37 & $6.4(4.6,8.7)$ \\
\hline & & & & & & & $(26-30)$ & & 425 & 19 & $4.5(2.7,6.9)$ \\
\hline & & & & & & & $(31-39)$ & & 396 & 3 & $0.7(0.2,2.2)$ \\
\hline Hince [32] & WA (Perth) & $\begin{array}{l}\text { Men attending } \\
\text { general practices }\end{array}$ & $\begin{array}{l}\text { Cross-sectional } \\
\text { survey }\end{array}$ & Urine & $63-100$ & M & $15-29$ & $2007-2008$ & 383 & 14 & $3.7(2.0,6.1)^{* *}$ \\
\hline Bilardi [33] & $\begin{array}{l}\text { VIC (urban } \\
\text { and rural) }\end{array}$ & $\begin{array}{l}\text { Women attending } \\
\text { general practices }\end{array}$ & $\begin{array}{l}\text { Cluster randomised } \\
\text { controlled trial }\end{array}$ & Any & $6.2-11.5$ & $\mathrm{~F}$ & $16-24$ & 2008-2009 & 843 & 66 & $7.8(6.1,9.9)^{*}$ \\
\hline Walker [34] & Australia-wide & $\begin{array}{l}\text { Women attending } \\
\text { primary health care } \\
\text { clinics }\end{array}$ & $\begin{array}{l}\text { Cross-sectional } \\
\text { survey }\end{array}$ & Swab & 66 & $\mathrm{~F}$ & $16-25$ & 2007-2008 & 738 & 25 & $3.4(1.5,5.3)$ \\
\hline
\end{tabular}

Studies are presented in order of publication year and author. * Confidence intervals calculated by authors. ** Re-calculated confidence intervals differ from those reported. ${ }^{\mathrm{A}}$ Median. ACT, Australian Capital Territory; Bris, Brisbane; F, female; GP, general practice, general practitioner; M, male; Melb, Melbourne; NA, not applicable; n.d., not determined; n.r., not reported; NSW, New South Wales; QLD, Queensland; VIC, Victoria; WA, Western Australia. Participant numbers reflect numbers from which epidemiological data was calculated, with sub-group numbers (e.g. by age or year) in brackets. 


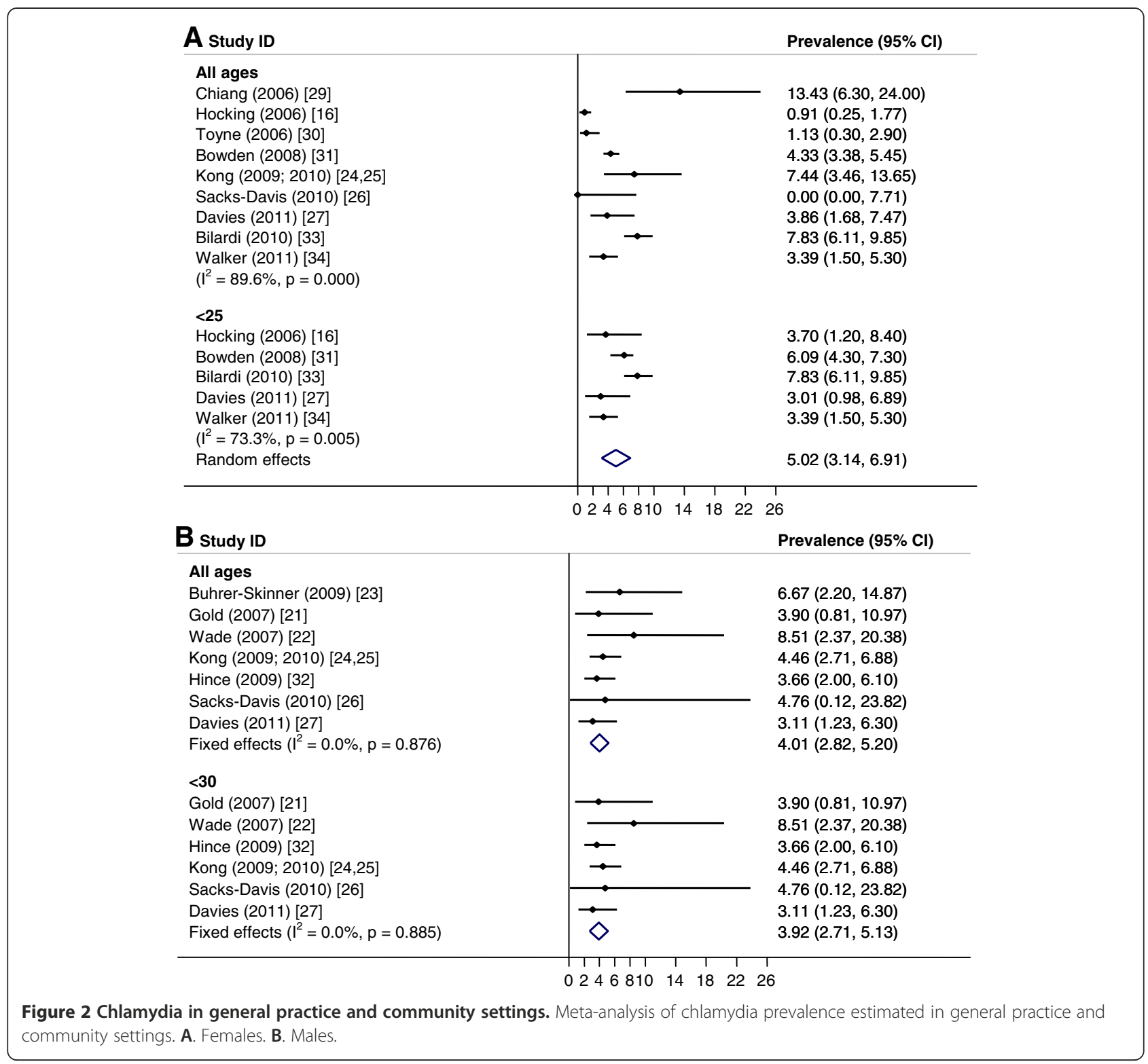

\section{General practice and community settings}

Eighteen studies (18 papers; 1 abstract) reported on chlamydia prevalence estimates from studies conducted in GP or community-based settings (Table 1) [16-34]. Seven reported on prevalence measured in GP clinics [28-34], while other studies recruited participants from community-based settings including sporting clubs (3) $[21,22,24,25]$, university or high school campuses (5) [1720,23], festivals (2) [23,26], backpacker hostels (2) [23,27], and a defense force unit (1) [23]. Only one study utilised a population-based sample of young women recruited from a telephone directory [16]. Participation rates were highest $(>80 \%)$ in studies conducted in sporting clubs $[21,22,24,25]$, and lowest in two GP-based RCTs of chlamydia testing interventions $(<11.5 \%)$ [31,33].
In community-based settings, reported prevalence estimates were $3.9-8.5 \%$ for men and $7.4 \%$ for women recruited from sporting clubs [21,22,24,25], 3.5-7.7\% among male and female backpackers [23,27], and 0.0$5.3 \%$ for young people in educational settings [1720,23]. The only population-based study reported a prevalence of $3.7 \%$ among sexually active 18-24-yearold women [16], with no population-based data available for men.

In general practice, chlamydia prevalence for women ranged from $1.1-13.4 \%$, although the highest and lowest estimates were from studies with either a small sample size [29], or a higher proportion of older women [29]. The most recent cross-sectional surveys, one in men [32] and one in women [34], had similar participation rates of 
over $60 \%$ and reported similar prevalence estimates for males and females (3.7\% and $3.4 \%$, respectively). Prevalence was higher in the two RCTs, at $5.1-7.8 \%$ among women aged 16-25 years; however, response rates were low $(<11.5 \%)$.

The majority of GP and community-based studies (14) provided prevalence estimates for those aged 30 years or less, with nine studies providing estimates for those aged 25 years or less, and just three providing age-stratified data $[16,27,31]$. For women, one clinic-based [31] and one community-based study [16] reported higher prevalence among women under 25 years, compared with older women: $6.1 \%$ and $3.7 \%$ versus $5.5 \%$ and $1.7 \%$, respectively. A third study measured prevalence in both male and female International backpackers [27] and reported a higher chlamydia prevalence in women aged over 25 years $(7.3 \%)$, compared with younger women (3.0\%); with the trend reversed in men $(1.6 \%$ versus

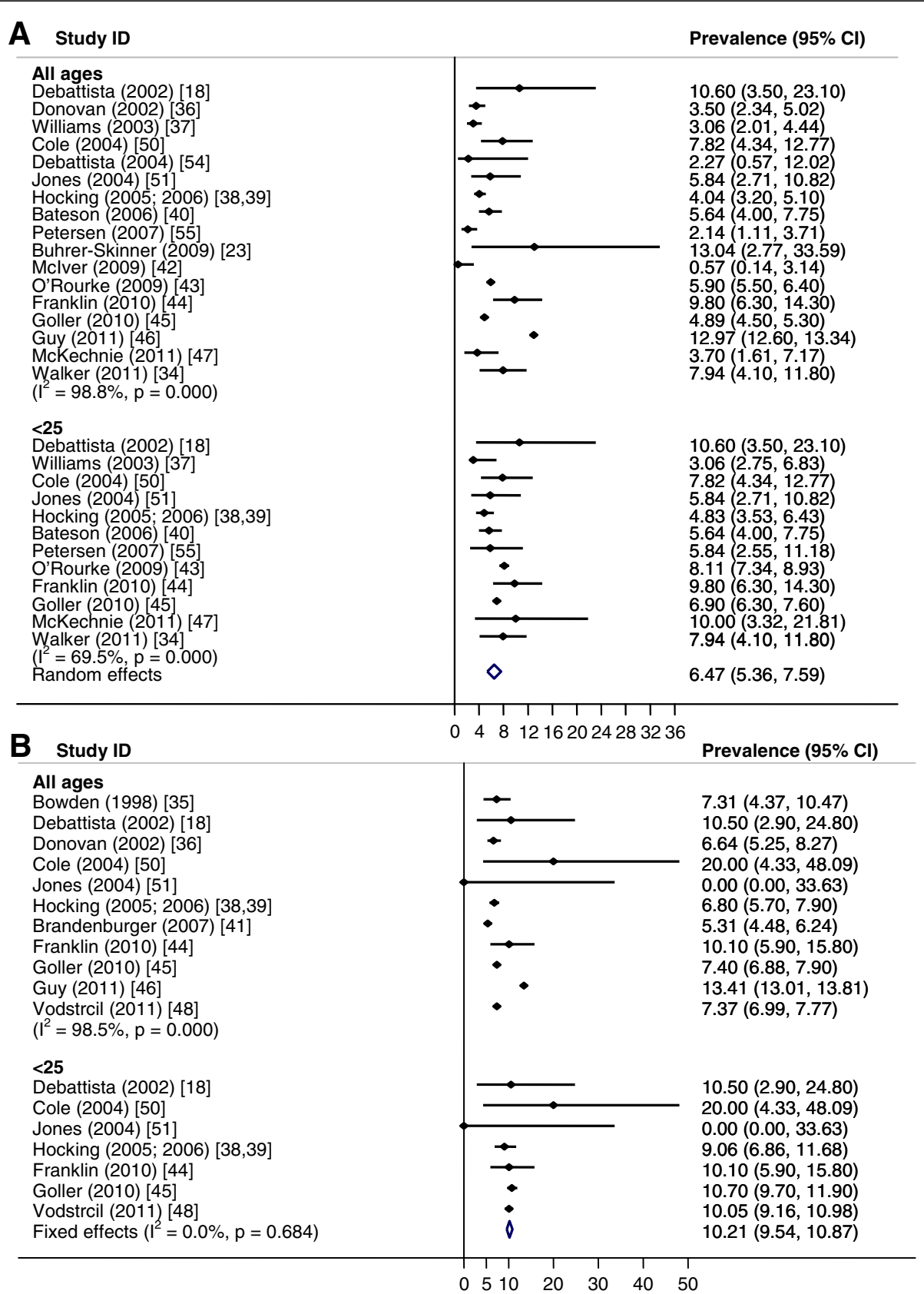

Figure $\mathbf{3}$ Chlamydia in sexual health clinics, youth services and other clinical settings. Meta-analysis of chlamydia prevalence estimated in sexual health clinics, youth services and other clinical settings. A. Females. B. Males. 
3.6\%). Only one study estimated prevalence over time, with no trend evident [18].

Pooled prevalence estimates for women aged $<25$ years or for women of any age group could not be calculated due to significant heterogeneity between studies $\left(\mathrm{I}^{2}>75 \%, \mathrm{p}<0.01\right)$. However, if studies conducted prior to 2006 were excluded, the pooled prevalence of women aged $<25$ years was $5.0 \%$ (CI: 3.1, 6.9; $\mathrm{I}^{2}=73 \%, \mathrm{p}<0.01$ ) (Figure 2A) and if the two RCTs with low response rates were excluded [31,33], the pooled prevalence for under 25 year old women was $3.3 \%$ (CI: $1.9,4.8 ; \mathrm{I}^{2}=0 \%$, $\mathrm{p}=0.96)$ and $2.6 \%\left(\mathrm{CI}: 1.0,4.1 ; \mathrm{I}^{2}=72 \%, \mathrm{p}<0.01\right)$ for women of all ages. For men, a pooled estimate of $3.9 \%$ (CI: 2.7, 5.1; $\mathrm{I}^{2}=0 \%, \mathrm{p}=0.88$ ) was calculated for men aged $<30$ years and $4.0 \%\left(\mathrm{CI}: 2.8,5.2 ; \mathrm{I}^{2}=0 \%, \mathrm{p}=0.88\right.$ ) for all ages (Figure 2B). There was only one study for $<25$-year-old men conducted in the period from 2006 onward and this reported a prevalence of $3.7 \%$ (CI: 0.4, 6.9) [27]; all studies for men $<30$ years were conducted post-2005. Pooled estimates by setting were not calculated because of significant heterogeneity between studies $\left(\mathrm{I}^{2}>75 \%, \mathrm{p}<0.01\right)$. However, if studies conducted prior to 2006 and the two RCTs with low response rates were excluded, the pooled prevalence was higher in GP clinics than in community-based studies (3.5\%; CI: 2.1, $4.9 ; \mathrm{I}^{2}=0 \%, \mathrm{p}=0.85$, versus $2.9 \%$; CI: $2.0,3.8 ; \mathrm{I}^{2}=0 \%$, $\mathrm{p}=0.47)$.

\section{Sexual health centres, youth health services and other clinical settings}

There were 24 studies (23 papers; 2 abstracts) reporting chlamydia prevalence estimates in clients attending sexual health or family planning clinics (14 studies) [34-48], youth centres (8) $[18,23,28,45,49-53]$ and other clinical settings (4) [45,54-56] (Additional file 1).

For studies conducted at sexual health clinics, the majority (7) were retrospective audits of patient records $[36,38,39,41,43,44,48,57]$, five were cross-sectional surveys $[34,37,40,42,47]$ and two were sentinel surveillance reports $[45,46]$. Sample sizes varied greatly, from 175 [42] to 59,720 [46]. Six studies provided estimates for women only $[34,37,40,42,43,47]$, three for men only $[35,41,48]$, and four for both males and females $[36,38,39,45,46]$; one study did not differentiate between males and females [44]. Prevalence estimate ranges were $5.3-13.4 \%$ for males and $0.6-13.0 \%$ for females, although the study with a prevalence of $0.6 \%$ excluded women $<18$ years and those with pelvic inflammatory disease [42]. Where age-stratified estimates were available, prevalence tended to be highest among those $<25$ years for both males and females [37-39,43,47,48].

Three studies reported on prevalence trends over time in sexual health clinics $[43,44,48]$. Two comprehensive analyses found that chlamydia prevalence increased by about $12 \%$ per year (from $4.2 \%$ in 2003 to $6.7 \%$ in 2007 ) among females [43] and by $3 \%$ per year (from $5.8 \%$ in 2002 to $8.0 \%$ in 2009) among heterosexual males [48] after adjusting for changes in patient demographics, clinical presentation or sexual behaviour over time.

Two cross-sectional surveys and one sentinel surveillance study compared chlamydia prevalence in sexual health and family planning clinics across multiple geographic locations. A study of women attending family planning clinics found a higher prevalence at an inner city clinic: $4.8 \%$ versus $1.7 \%$ at a suburban clinic [37]. Younger women $(<25$ years $)$ attending the inner-city clinic had a higher prevalence (6.2\%), whereas the prevalence for this age group at the suburban clinic was $1.7 \%$. Similarly, higher prevalence estimates in inner-city clinics compared with suburban clinics were reported by Bateson and colleagues [40] (9.7\% versus 3.1\%).

For the eight studies that determined prevalence at youth centres [23,28,45,49-53], prevalence estimates ranged from $0-20.0 \%$. One study reported increased prevalence from one year to the next $(2.7 \%$ in $2006 / 07$ vs. $11.3 \%$ in 2007/08); however, the increase likely reflected a change in the mode of operation from an appointment-based to drop-in service [53]. Sample sizes in this setting were also frequently low, and half did not report data for males and females separately [28,49,52,53].

In non-primary care clinical settings, the chlamydia prevalence for women attending a colposcopy clinic was reported to be higher in women aged 25 years or less (5.8\%) compared with older women (0.9\%) [55]. A prevalence of just $0.2 \%$ was found for women attending a hospital in vitro fertilisation (IVF) service for investigation of infertility [54]; however, higher estimates for hospitalbased studies of $3.1 \%$ for women [45] and 5.5\% for men and women [56] were also reported. These divergent estimates were possibly due to age differences in study participants, although the precise age range of participants was not available for two of the studies [45,54].

Meta-analysis was performed for males and females separately by age group (Figure 3 ). The pooled prevalence for women $<25$ years was $6.2 \%$ (CI: 5.1, 7.4; $\left.I^{2}=73 \%, p<0.01\right)$. It was not possible to calculate the pooled prevalence for women of all ages because of significant heterogeneity between studies $\left(\mathrm{I}^{2}=99 \%\right.$, $\mathrm{p}<0.01$ ) (Figure $3 \mathrm{~A}$ ). When analysed by setting, there was significant heterogeneity for studies conducted in sexual health or family planning clinics, but for women attending youth centres, the pooled prevalence was $6.8 \%$ (CI: $3.8,9.7 ; \mathrm{I}^{2}=0 \%, \mathrm{p}=0.51$ ) for women $<25$ years and $7.0 \%$ (CI: 4.1, 9.9; $\mathrm{I}^{2}=0 \%, \mathrm{p}=0.59$ ) for women of all ages. Within other clinical settings, the pooled prevalence was $2.1 \%$ (CI: $0.9,3.4 ; \mathrm{I}^{2}=0 \%, \mathrm{p}=0.97$ ) for women of all ages. 
For men, the pooled prevalence for men of all ages across all study sites was not calculated due to heterogeneity $\left(\mathrm{I}^{2}=98.8 \%, \mathrm{p}<0.01\right)$; however, the pooled prevalence was $10.2 \%$ (CI: 9.5, 10.9; $\mathrm{I}^{2}=0 \%, \mathrm{p}=0.41$ ) for men $<25$ years (Figure 3B). In sexual health/family planning clinics, the pooled prevalence was 9.9\% (CI: 9.1, 10.8; $\left.\mathrm{I}^{2}=0 \%, \mathrm{p}=0.45\right)$ for men $<25$ years; it was not possible to calculate the pooled prevalence for men of all ages attending sexual health/family planning clinics because of significant heterogeneity between studies $\left(\mathrm{I}^{2}=99 \%, \mathrm{p}<0.01\right)$. In youth centres, the pooled prevalence was $8.7 \%$ (CI: 0, 28.2; $\left.\mathrm{I}^{2}=50 \%, \mathrm{p}=0.16\right)$ among men $<25$ years.

\section{Pregnant women}

Eleven studies (10 papers; 1 abstract) reported prevalence estimates in pregnant women, from a range of urban and rural/remote locations (Additional file 2) [58-68]. Sample sizes ranged from 70 [59] to 1175 [58] participants, and participation rates in most studies were high (52-99.8\%).

Reported chlamydia prevalence estimates were diverse, ranging from $2.8-14.4 \%$, with prevalence highest among young and/or Indigenous women. In studies with agestratified data, all reported higher prevalence estimates in women $<25$ years $(4.5-22.0 \%)$, compared with participants of all ages (2.7-14.4\%) [62-64]. Three studies of women aged 20 years or younger reported estimates of $5.7-13.7 \%$ $[60,61,65]$, and three further studies where age was not specified reported prevalence estimates of 2.8\% [59], 3.9\% [66] and $12.3 \%$ [68]. A large study conducted in public hospital antenatal clinics in Victoria reported a prevalence of $3.2 \%$ among women $<25$ years [67].

For pregnant Indigenous women, rates of infection ranged from $2.9-14.4 \%[59,63,64,68]$. A comparison of prevalence in Indigenous versus non-Indigenous women reported higher estimates in Indigenous women: 9.1\% compared with $2.7 \%$ overall [64]. One study reporting age-stratified data found a prevalence of $14.4 \%$ overall, with higher prevalence in teenagers (32.6\%) [63]. This is also higher than the two hospital-based teen studies, despite both having high proportions of Indigenous participants: $30.3 \%$ [60] and 74.6\% [61].

It was not possible to calculate pooled prevalence estimates because of significant heterogeneity between the studies $\left(\mathrm{I}^{2}=89.5 \%, \mathrm{p}<0.01\right)$, which persisted when the studies were stratified by age $\left(<25\right.$ years, $\mathrm{I}^{2}=88.6 \%$, $\mathrm{p}<0.01$; Figure 4).

\section{Indigenous Australians}

Prevalence estimates for Indigenous Australians were reported in 16 reviewed studies (17 papers; 1 abstract) [18,23,44,59,63,64,68-78] (Additional file 3). Sample sizes varied from 20 [23] to 2817 [72] and while participation rates were reported in only seven of the studies, four cited rates of over $80 \%$. The majority of studies were conducted in rural or remote areas (5) [59,69,71-73,79] or regional centres (6) $[23,63,68,74,76-78]$. Only three studies were conducted in large capital cities [18,23,44], and one sentinel surveillance study reported data from both urban and rural locations [77].

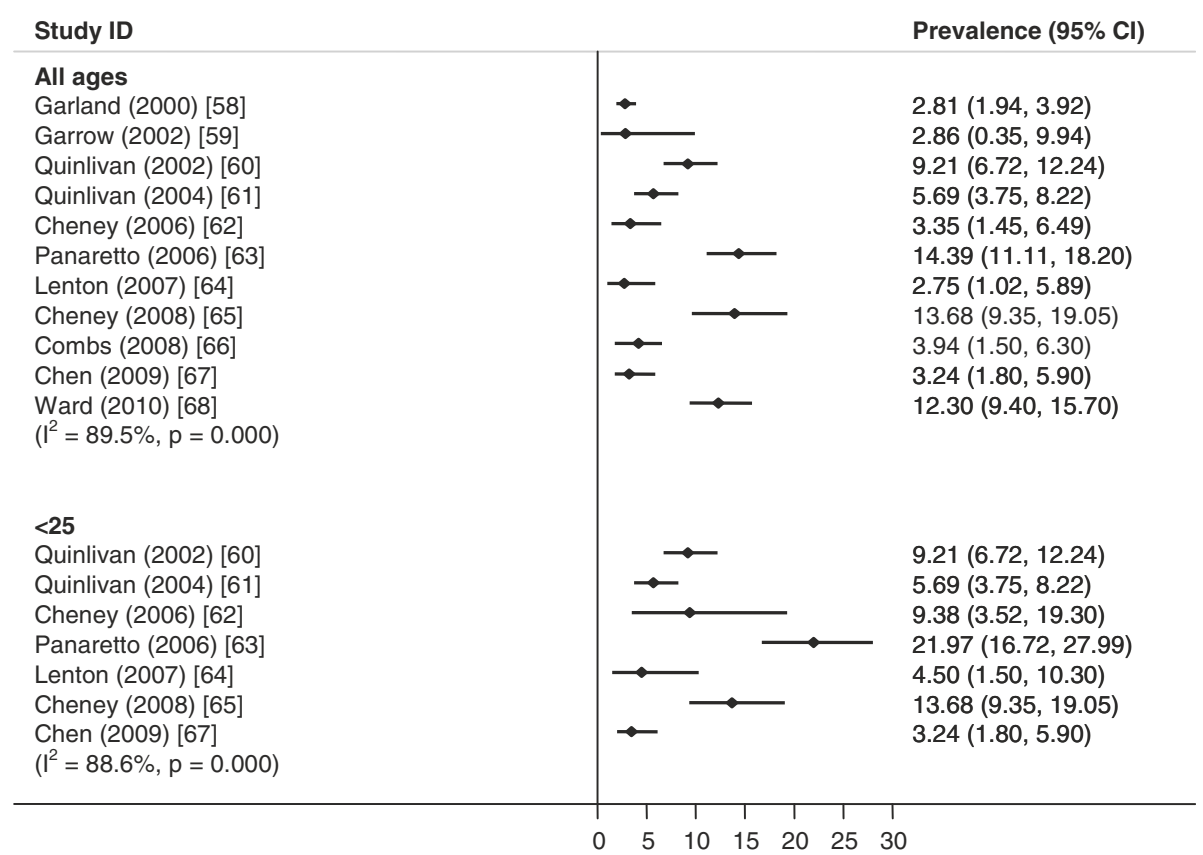

Figure 4 Chlamydia in pregnant women. Meta-analysis of chlamydia prevalence estimated in pregnant women. 


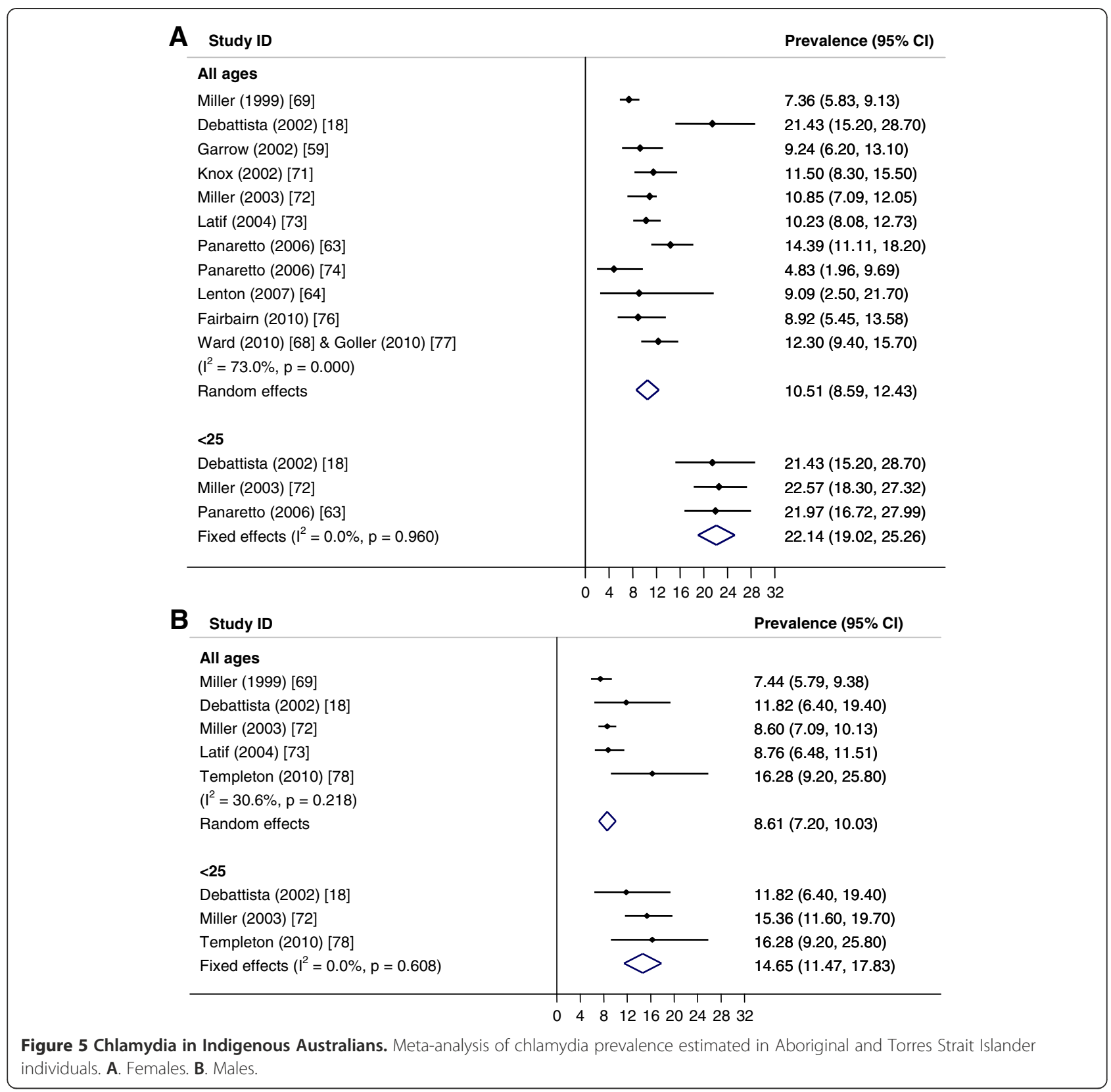

Estimates ranged from $4.8-14.4 \%$ for women, and 8.6$16.3 \%$ for men. Three studies only reported combined prevalence estimates for men and women (4.4-15\%). The highest reported estimates were in younger age groups. Two studies reported age-stratified data, with prevalence very high in both male and female teens (males 13.0-18.8\%; females 17.4-34.3\%), and then decreasing with age [72,77]. A further study of Indigenous youths reported high estimates of $21.0 \%$ for males and $11.8 \%$ for females aged $15-18$ years [18]; while pregnant Indigenous teens recorded prevalence estimates ranging from $2.9 \%$ [59] to $32.6 \%$ [63].
In studies that compared Indigenous with nonIndigenous individuals, three of four studies reported higher prevalence estimates for Indigenous study participants $[23,63,64]$. One study found that, when considered separately, women identifying as Torres Strait Islanders had a prevalence of $9.7 \%$, whereas Aboriginal women had a prevalence of just $3.5 \%$, lower than for nonIndigenous women in the study (3.8\%) [63]. A single study conducted in a large urban sexual health clinic found a lower prevalence in Indigenous (6.7\%) compared with non-Indigenous clients (9.4\%), although this was not a significant difference [44]. 


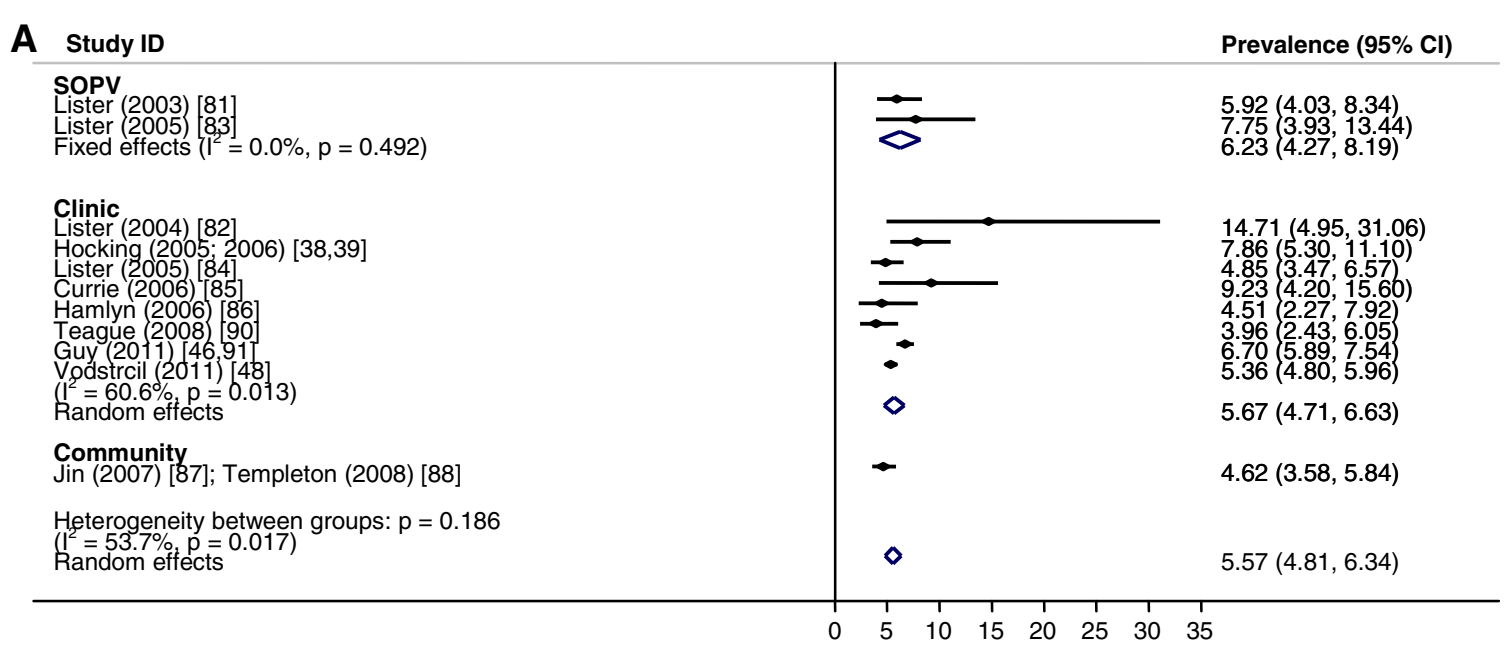

\section{B Study ID}

\section{SOPV}

Debattista (2000) [79]

Debattista (2002) [80]

Lister (2003) [81]

Lister (2005) [83]

Fixed effects $\left(I^{2}=0.0 \%, p=0.442\right)$

Clinic

Lister (2004) [82]

Hocking $(2005 ; 2006)[38,39]$

Lister (2005) [84]

Currie (2006) [85]

Hamlyn (2006) [86]

Teague (2008) [90]

Guy (2011) [46,91]

Vodstrcil (2011) [48]

$\left(l^{2}=80.1 \%, p=0.000\right)$

Community

Jin (2007) [87]; Templeton (2008) [88]
Prevalence $(95 \% \mathrm{Cl})$

$3.33(0.69,9.43)$

$4.35(1.90,8.39)$

$1.76(0.80,3.30)$

$1.45(0.18,5.14)$

$2.05(1.03,3.08)$

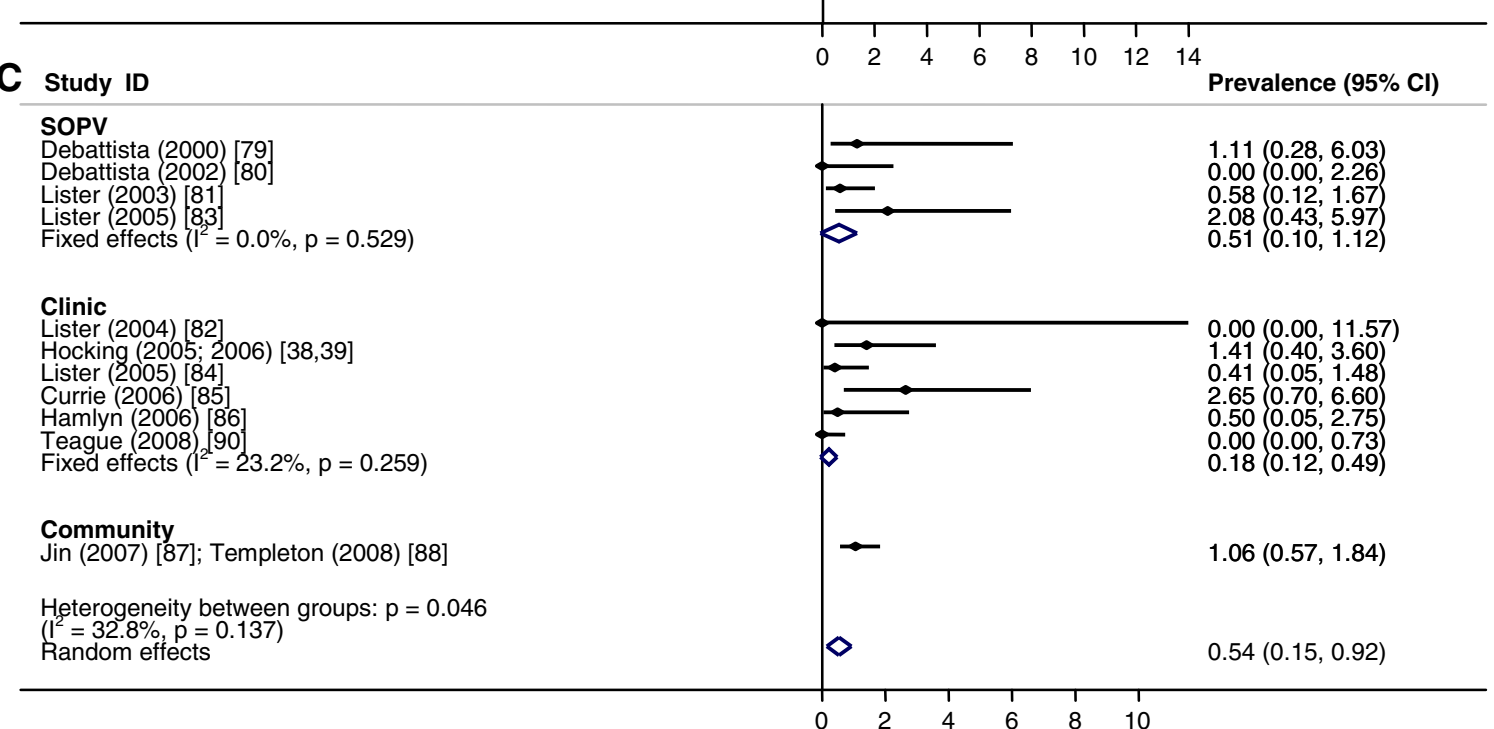

Figure 6 Chlamydia in men who have sex with men (MSM). Meta-analysis of chlamydia prevalence estimated in men who have sex with men (MSM). A. Rectal. B. Urethral. C. Pharyngeal. 
Just one study reported prevalence estimates over time $[69,70]$, finding that prevalence decreased for both men and women over the first study period (1998-2000), from $8.8 \%$ to $7.2 \%$ in men, and from $9.1 \%$ to $7.2 \%$ in women. However, this was linked to the introduction of a sexual health intervention, and the falls were not significant [69]. The odds of testing positive for chlamydia decreased significantly by $12 \%$ per year (CI: 8,16 ) between 1996 and 2002, but no further reduction was observed between 2003 and 2006 [70].

Pooled prevalence estimates were higher for women than for men and higher among those aged $<25$ years (Figure 5). Among women, the pooled prevalence for those $<25$ years was $22.1 \%$ (CI: 19.0, 25.3; $\mathrm{I}^{2}=0 \%$, $\mathrm{p}=0.96)$ and across all ages, $10.5 \%$ (CI: 8.6, 12.4; $\left.\mathrm{I}^{2}=73 \%, \mathrm{p}<0.01\right)$. For men, the pooled prevalence for $<25$-year-olds was $14.7 \%$ (CI: $11.5,17.8 ; \mathrm{I}^{2}=0 \%, \mathrm{p}=0.61$ ) and across all ages, 8.6\% (CI: 7.2, 10.0; $\mathrm{I}^{2}=31 \%$, $\mathrm{p}=0.22$ ).

\section{Men who have sex with men (MSM)}

Sixteen studies (19 papers) were identified that measured chlamydia prevalence in MSM [38,39,44-46,48,79-91] (Additional file 4). Sample sizes ranged from 80 [82] to 11,777 [91], and settings included sexual health centres (11 studies) [38,39,44-46,48,79,81,84,85,89-91], hospitals and other clinical settings (3) $[85,86,90]$, and male-only entertainment or sex-on-premises venues (SOPVs; 4) [79-81,83]. One study involved community-based cohorts of HIV-positive and HIV-negative MSM [87,88]. Where reported, participation rates were high in clinical settings (77-85\%), but much lower in SOPVs (24-50\%).

Overall, 12 studies reported prevalence estimates for urethral infection, 10 for rectal infection, and 10 for pharyngeal infection, while five did not provide sitespecific estimates. The prevalence of rectal infection was consistently more than $30 \%$ higher than urethral infection and ranged from $4.0 \%$ among HIV-positive men attending HIV clinics [90] to $14.7 \%$ among men attending a sexual health clinic [84]. Urethral infection prevalence ranged from $1.0 \%$ [86] to 5.0\% [84]. Estimates for pharyngeal infection were low, ranging from $0.0 \%$ in both clinical and SOPV settings $[80,82,90]$ to $2.7 \%$ [85]. A large well-conducted cohort study found the prevalence of rectal and urethral chlamydia at the time of recruitment to be higher among HIV-positive compared with HIV-negative men $(5.9 \%$ versus $4.4 \%$ and $0.9 \%$ versus $2.2 \%$ ), although this was not statistically significant $[87,88]$.

The pooled prevalence for rectal chlamydia was $5.6 \%$ (CI: 4.8, 6.3; $\mathrm{I}^{2}=54 \%, \mathrm{p}=0.02$ ) and was similar between men tested in SOPVs (6.2\%: CI: 4.3, 8.2; $\left.\mathrm{I}^{2}=0 \%, \mathrm{p}=0.49\right)$ and in clinics $\left(5.7 \%, \mathrm{CI}: 4.7,6.7 ; \mathrm{I}^{2}=61 \%, \mathrm{p}=0.01\right)$ (Figure 6A). It was not possible to calculate an overall pooled prevalence for urethral chlamydia because of heterogeneity between studies $\left(\mathrm{I}^{2}=86 \%, \mathrm{p}<0.01\right)$ (Figure 6B). This was also the case for clinic-based urethral chlamydia prevalence $\left(\mathrm{I}^{2}=80 \%, \mathrm{p}<0.01\right)$. The pooled prevalence for urethral chlamydia among men tested at SOPVs was $2.1 \%\left(\mathrm{CI}: 1.0,3.1 ; \mathrm{I}^{2}=0 \%, \mathrm{p}=0.44\right)$. For pharyngeal chlamydia (Figure $6 \mathrm{C}$ ), the pooled prevalence across settings was $0.5 \%$ (CI: $0.2,0.9 ; \mathrm{I}^{2}=33 \%$, $\mathrm{p}=0.14)$, and was similar between SOPVs $(0.5 \%$; CI: 0 , $\left.1.1 ; \mathrm{I}^{2}=0 \%, \mathrm{p}=0.53\right)$ and clinical settings $(0.3 \%$; CI: 0 , $\left.0.8 ; \mathrm{I}^{2}=23 \%, \mathrm{p}=0.26\right)$.

\section{High-risk populations}

Twelve papers were identified that estimated chlamydia prevalence in potentially high-risk populations $[18,38,44,60,78,89,92-97]$ (Additional file 5). Five measured chlamydia prevalence in sex workers (legal and illegal) [38,44,92-94], four in individuals in prison or juvenile detention $[18,78,95,96]$, two in drug users [60,97], and one in STI contacts [89]. Participation rates, where reported, were high (49-87\%), and sample sizes varied from 86 [78] to 1766 [93].

Prevalence in sex workers ranged from 1.2-8.3\%. Three of the five studies did not differentiate between male and female sex workers, although all had predominantly female participants [38,92,93]. Brothel workers had lower prevalence estimates in two studies, compared with street sex workers [92,93]. However, a study of illegal brothel sex workers in Western Australia found a low prevalence of $2.7 \%$ [94]. Two clinical audits conducted at sexual health centres found divergent estimates of 3.3\% [38] and 7.8\% [44] for female sex workers, and $11.1 \%$ for male sex workers [44].

For prisoners, a study by Mak and colleagues [95] reported that $3 \%$ of male prisoners tested positive for chlamydia upon admission to prison. A larger study conducted across male and female prisons in both metropolitan and regional locations recorded an overall prevalence of $7.3 \%$ [96]. For the juvenile detainees, chlamydia prevalence for females was measured at over 20 per cent in two separate studies $[18,96]$, higher than for male juveniles (range 2.0-16.3\%).

In a sample of injecting drug users, $6 \%$ tested positive for chlamydia [97]; and in pregnant teens, chlamydia was more prevalent in multi-drug- (25.8\%) and marijuana-users (9.7\%), compared with non-users (7.7\%). The highest prevalence (33.1\%) was reported for clients attending a sexual health centre as contacts of chlamydia, non-gonococcal urethritis and PID [89].

\section{Discussion}

We found that chlamydia prevalence estimates were highly variable, with rates generally higher among young Australians, Indigenous Australians, and MSM. Other 
high-risk populations, including youth clinic attendees, pregnant teenagers and prison inmates, were also found to have higher prevalence estimates. This review builds considerably on the earlier review by Vajdic et al. [12], and a key strength is that studies were limited to those that used the more sensitive and specific NAAT testing methods.

Measuring the true prevalence of chlamydia in a community is a challenging task, with non-population-based studies frequently suffering from sampling bias and low participation rates $[98,99]$. Studies utilising populationbased data on chlamydia prevalence are rare, both in Australia and the UK $[12,100]$, and this review identified just one survey that recruited participants from the general population. This study, of women recruited from the telephone directory, was limited by its small sample size and low participation rate (43\%) [16]. Both community-based and clinic-based sampling is subject to participation bias: community-based sampling often relies on convenience sampling, where participants are able to self-select; and clinic-based sampling is likely to bias towards symptomatic and higher risk participants, and towards more health care-seeking, and therefore well-educated, Australian-born participants [34]. This can also be true of population-based studies [16]. Sexual health centre studies can be particularly susceptible to bias towards symptomatic and high-risk groups, although as a research setting, they can provide large sample sizes at low costs, especially through clinic audits.

Community-based studies are important for estimating chlamydia prevalence as notification rates are known to under-estimate infection levels, as they are highly influenced by testing rates. The only population-based estimate identified in this review reported a prevalence of $3.1 \%$ among all 18 to 24 year old women in 2003-2004 [16]; no similar study has been conducted in men. This would translate into over 10,500 cases of chlamydia among Victorian women aged 15-24 years in 2004 (and 10,900 cases in men of the same age), which is considerably higher than the 7694 cases notified among both men and women of any age in Victoria that year [2], highlighting that notification data considerably underestimate of the true number of individuals infected.

A key factor that limits the conclusions that can be drawn from the studies included in the review is the high level of heterogeneity both within and between the populations studied. In most key populations reviewed, pooled prevalence estimates could not be calculated, even after stratifying data by age and sex of individuals tested. This was particularly true for female data. Although we calculated pooled prevalence estimates within the different population sub-groups, it is important that these be interpreted with caution and only indicative of the true prevalence.
The high level of variability between studies also prevented prevalence trends over time to be assessed, despite the review period spanning almost 15 years. Only seven individual studies determined time trends $[18,36,43,44,48,69]$, three finding a statistically significant increase in prevalence over time $[36,43,48]$; and two reporting no change over time $[18,44]$. One study in an Indigenous community found a decrease over time, however, this was associated with an STI intervention to increase testing rates [69]. Despite the variability, the studies by Vodstrcil et al. [48] and O'Rourke et al. [43] both conducted in sexual health clinics - provide evidence to support an increasing chlamydia prevalence among heterosexual men and women in Australia, because these studies had large sample sizes and adjusted for changes in sexual behaviour over time. Both Australian and international data show that sexual risk behaviour has changed over the last decade with increasing numbers of sex partners reported by young adults. The National Survey of Sexual Attitudes and Lifestyles, a sexual behaviour survey conducted in the United Kingdom in 1990 and again in 2000 [101] showed that the number of heterosexual partners in the preceding five years increased significantly for both sexes. Australian data show that age at first sexual intercourse has decreased, with women aged 16-24 years reporting a median age of 16 at first sexual intercourse compared with 19 for women aged 50-59 years [102].

Similar to previous systematic reviews in both the UK and Australia $[12,100]$, we found that the study setting influenced the prevalence estimates reported; however, significant heterogeneity again hampered comparisons in most cases. For men, prevalence was higher in sexual health and family planning clinics compared with GP and community-based settings. This was similar for women aged $<25$ years; however, this difference was not statistically significant. GP-based studies, similar to those conducted by Vodstrcil et al. [48] and O'Rourke et al. [43] in sexual health centres, would greatly enhance our ability to compare between these clinical settings. Between-setting comparisons are especially fraught for men; only one study conducted in general practice reported prevalence among men alone [32], and no studies reported chlamydia prevalence in heterosexual men from a population-based sample.

Where studies reported age-based estimates, younger participants had higher prevalence estimates than older participants. These data are consistent with the national notification data that show that notification rates are highest among those $<25$ years [2] and are also consistent with sexual behaviour data which show that numbers of sexual partners are highest in these younger age groups [103]. We also found high rates among disadvantaged youth and young people attending youth clinics. 
These findings of increased chlamydia among young men and women echo those findings in overseas prevalence studies [98,99].

Chlamydia notification rates over the past 15 years have been consistently higher in women compared with men; however, this did not emerge as a robust trend in this review. Higher female notification rates can probably be attributed to differences in chlamydia testing rates. In Australia, recent Medicare data indicates that about $12-13 \%$ of sexually active young women and 3$4 \%$ of young men are tested for chlamydia each year [11]. As chlamydia testing rates increase in Australia, notification data will be able to provide a better estimate of the population prevalence of chlamydia.

We found that prevalence estimates were comparable among heterosexual men and women; however, the picture is neither complete nor consistent. In the general practice setting, no studies directly compare prevalence between men and women; and in sexual health clinics, prevalence tended to be higher among men. This is probably because men are more likely to attend a sexual health centre due to the presence of urethral symptoms [104]. Curiously, fifteen studies were identified that did not report male and female data separately, thereby excluding the data from calculations of pooled prevalence estimates. A number of recent studies reporting chlamydia prevalence in men attending sporting clubs $[21,22,24,25]$ and general practices [32] have started to address the predominance of female studies, which has been previously noted [12]; however, there remains a need for additional studies that directly compare men and women in community and clinical settings.

Similar discrepancies between notification data and population-based prevalence surveys have also been observed in the USA. In 2010, the notification rate reported to the Centers for Disease Control and Prevention was 2.6 times higher for women (610.6 per 100,000 population) than for men (233.7 per 100,000) [105]; rates in 2002 differed by almost four-fold between the sexes. By comparison, prevalence estimates reported in the National Health and Nutrition Examination Survey (NHANES) conducted between 1999-2002 were similar in women (2.5\%; CI: $1.8,3.4)$ and men (2.0\%; CI: $1.6-2.5)$ [106]. Although the prevalence was twice as high in women aged 14-19 years (4.6\%) compared to men $(2.3 \%)$, the trend was reversed in the 20-29 year age group, where more men were infected (3.2\%) than women (1.9\%) [106]. These data underscore the fact that at low testing rates, notification data do not provide a full picture of the prevalence of chlamydia infection in the community.

In contrast to heterosexual men, several studies explored chlamydia prevalence among MSM, with most providing estimates from multiple anatomical sites (Additional file 4). In line with data from the UK and
USA $[107,108]$, prevalence was highest in rectal swabs compared with urethral samples, and lowest in pharyngeal swabs. This highlights the importance of rectal chlamydia screening in MSM and the need to include both urethral and rectal sampling when conducting chlamydia prevalence surveys in this population group as recommended in national guidelines [109]. Unfortunately, Australian national notification data do not include site of infection nor sexual orientation, thereby reducing our ability to monitor trends in this population group over time.

The key gaps identified by Vajdic et al. [12] still remain today, including a need for population-based data for young men and women and systematically collected serial sentinel data with which trends in chlamydia prevalence over time can be monitored, particularly within the nationally identified target risk groups (young men and women, MSM and Indigenous Australians) [110]. The further advances in information technology including improvements in medical records software, the development of data extraction software [111] and data linkage [112], will facilitate the collection of standardised and detailed socio-demographic, behavioural and clinical data (including presence or absence of chlamydia-related symptoms) from sentinel sites. This will allow trends to be evaluated over time within different risk groups, adjusting for any changes in behavioural data and clinical presentation. The Australian Collaboration for Chlamydia Enhanced Sentinel Surveillance (ACCESS; www.accessstudy.org) [44] and the Victorian Primary Care Network for Sentinel Surveillance (VPCNSS) [45] are both important sentinel surveillance projects that collect detailed demographic, clinical and behavioural data with which trends in risk groups can be monitored over time. It is vital that such surveillance systems continue to be funded. Further, the Australian Chlamydia Control Effectiveness Pilot (ACCEPt; www.accept.org.au), a randomised controlled trial of chlamydia testing in general practice, is collecting chlamydia testing data from about 250 GP clinics across Victoria, New South Wales, Queensland and South Australia and will provide trends in chlamydia positivity over time among young men and women.

\section{Conclusions}

This comprehensive systematic review identified 76 studies reporting prevalence data for individuals tested for anogenital or pharyngeal chlamydia and provides an up-to-date summary of the underlying burden of chlamydia in Australian populations. The review highlights that the burden of chlamydia in Australia is greatest among young adults, Indigenous populations and MSM and identifies important gaps in the surveillance and monitoring of chlamydia infection in Australia. Given that that the Australian Government is currently pilot 
testing chlamydia screening as a national program and State Governments continue to fund chlamydia control activities, it is vital that good sentinel surveillance systems continue.

\section{Additional files}

Additional file 1: Studies reporting chlamydia prevalence data, identified in sexual health clinics, youth services and other clinical settings. Studies are presented in order of publication year and author. * Confidence intervals calculated by report authors. ${ }^{*}$ Re-calculated confidence intervals differ from those reported. ${ }^{\mathrm{A}}$ Median. F, female; M, male; Melb, Melbourne; NA, not applicable; n.d., not determined; n.r., not reported; NSW, New South Wales; NT, Northern Territory; QLD, Queensland; VIC, Victoria; WA, Western Australia. Participant numbers reflect numbers from which epidemiological data was calculated, with sub-group numbers (e.g. by age or year) in brackets.

Additional file 2: Studies reporting chlamydia prevalence data, identified in pregnant women. Studies are presented in order of publication year and author. ${ }^{*}$ Confidence intervals calculated by authors. ** Re-calculated confidence intervals differ from those reported.

A Median. Melb, Melbourne; NA, not applicable; n.d., not determined; n.r., not reported; NSW, New South Wales; QLD, Queensland; VIC, Victoria; WA, Western Australia. Participant numbers reflect numbers from which epidemiological data was calculated, with sub-group numbers (e.g. by age or year) in brackets.

Additional file 3: Studies reporting chlamydia prevalence data, identified in Indigenous Australians. Studies are presented in order of publication year and author. ${ }^{*}$ Confidence intervals calculated by authors. ** Re-calculated confidence intervals differ from those reported.

A Median. Bris, Brisbane; F, female; GP, general practice, general practitioner; M, male; Melb, Melbourne; NA, not applicable; n.d., not determined; n.r., not reported; NSW, New South Wales; NT, Northern Territory; QLD, Queensland; SA, South Australia; WA, Western Australia. Participant numbers reflect numbers from which epidemiological data was calculated, with sub-group numbers (e.g. by age or year) in brackets.

Additional file 4: Studies reporting chlamydia prevalence data, identified in men who have sex with men. Studies are presented in order of publication year and author. * Confidence intervals calculated by report authors. ${ }^{* *}$ Re-calculated confidence intervals differ from those reported. ${ }^{A}$ Median. ACT, Australian Capital Territory; HIV+, HIV-positive; HIV-, HIV-negative; Melb, Melbourne; NA, not applicable; n.d., not determined; n.r., not reported; NSW, New South Wales; Ph, Pharynx; QLD, Queensland; R, rectum; SHC, sexual health centre; U, urethra; VIC, Victoria. Participant numbers reflect numbers from which epidemiological data was calculated, with sub-group numbers (e.g. by age or year) in brackets.

Additional file 5: Studies reporting chlamydia prevalence data, identified in high-risk populations. Studies are presented in order of publication year and author. ${ }^{*}$ Confidence intervals calculated by authors. ** Re-calculated confidence intervals differ from those reported.

A Median. Bris, Brisbane; broth, brothel; CBD, central business district; $F$, female; M, male; Melb, Melbourne; NA, not applicable; n.d., not determined; n.r., not reported; NSW, New South Wales; QLD, Queensland; st, street; WA, Western Australia. Participant numbers reflect numbers from which epidemiological data was calculated, with sub-group numbers (e.g. by age or year) in brackets.

\section{Abbreviations}

ACT: Australian capital territory; Bris: Brisbane; Cl: 95\% confidence interval; GP: General practice, general practitioner; Melb: Melbourne; MSM: Men who have sex with men; NA: Not applicable; NAAT: Nucleic acid amplification test; n.d.: Not determined; n.r.: Not reported; NSW: New South Wales;

NT: Northern Territory; PID: Pelvic inflammatory disease; QLD: Queensland; SA: South Australia; SOPV: Sex on premises venue; VIC: Victoria; WA: Western Australia.

\section{Competing interests}

The authors declare that they have no competing interests.

\section{Authors' contributions}

$J S H, D L$ and DCN conceived of the study, and participated in its design and coordination. DL and DCN conducted the literature search and systematic review. JSH performed the meta-analysis. DL, DCN, RJG, HA, MYC, CKF and JSH contributed to drafting the manuscript. All authors read and approved the final manuscript.

\section{Acknowledgements}

This study was financially supported by funding from the Department of Health, Victorian State Government, Australia.

\section{Author details}

${ }^{1}$ School of Population Health, University of Melbourne, Carlton, Victoria, Australia. ${ }^{2}$ The Kirby Institute, University of New South Wales, Darlinghurst, New South Wales, Australia. ${ }^{3}$ Melbourne Sexual Health Centre, Alfred Hospital, Carlton, Victoria, Australia.

Received: 30 November 2011 Accepted: 3 April 2012

Published: 14 May 2012

\section{References}

1. Newman L, Stirzaker S, Knuckey D, Robinson K, Hood J, Knope K, Fitzsimmons G, Martin N, Siripol S, Gajanayake I, Kaczmarek M, Barr I, Hii A, Foxwell R, Owen R, Wright P, Fitzsimmons G, Sanders L, Barry C, Barker S, Ormond J, Liu C: Australia's notifiable disease status, 2008: annual report of the National Notifiable Diseases Surveillance System. Commun Dis Intell 2010, 34:157-224.

2. National Notifiable Diseases Surveillance System http://www9.health.gov.au/ cda/source/cda-index.cfm.

3. Cates W Jr, Wasserheit JN: Genital chlamydial infections: Epidemiology and reproductive sequelae. Am J Obstet Gynecol 1991, 164:1771-1781.

4. Haggerty CL, Gottlieb SL, Taylor BD, Low N, Xu FJ, Ness RB: Risk of sequelae after Chlamydia trachomatis genital infection in women. J Infect Dis 2010, 202:S134-S155.

5. Schachter J: Biology of Chlamydia trachomatis. In Sexually Transmitted Diseases. Edited by Holmes K, Sparling P, Stamm W, Piot P, Wasserheit J, Corey L, Cohen MS. New York: McGraw-Hill; 2008:555-574. ISBN 4th.

6. Weström L, Joesoef R, Reynolds G, Hagdu A, Thompson SE: Pelvic inflammatory disease and fertility: a cohort study of 1,844 women with laparoscopically verified disease and 657 control women with normal laparoscopic results. Sex Transm Dis 1992, 19:185-192.

7. Fernandez JL, Ramos B, Santiso R, Agarwal A, Gosalvez J, Gallegos G: Frequency of sperm cells with fragmented DNA in males infected with Chlamydia trachomatis and Mycoplasma sp, determined with the sperm chromatin dispersion (SCD) test. Fertil Steril 2007, 88:S5-S5.

8. Idahl A, Boman J, Kumlin U, Olofsson Jl: Demonstration of Chlamydia trachomatis $\lg G$ antibodies in the male partner of the infertile couple is correlated with a reduced likelihood of achieving pregnancy. Hum Reprod 2004, 19:1121-1126.

9. Fleming DT, Wasserheit JN: From epidemiological synergy to public health policy and practice: the contribution of other sexually transmitted diseases to sexual transmission of HIV infection. Sex Transm Infect 1999, 75:3-17.

10. The Kirby Institute: Bloodborne viral and sexually transmitted infections in Aboriginal and Torres Strait Islander People: Surveillance and Evaluation Report 2011. Sydney: University of New South Wales; 2011.

11. Kong FYS, Guy RJ, Hocking JS, Merritt T, Pirotta M, Heal C, Bergeri I, Donovan B, Hellard ME: Australian general practitioner chlamydia testing rates among young people. Med J Aust 2011, 194:249-252.

12. Vajdic CM, Middleton M, Bowden FJ, Fairley CK, Kaldor JM: The prevalence of genital Chlamydia trachomatis in Australia 1997-2004: a systematic review. Sex Health 2005, 2:169-183.

13. Moher D, Liberati A, Tetzlaff J, Altman DG, The PRISMA Group: Preferred reporting items for systematic reviews and meta-analyses: the PRISMA statement. PLOS Med 2009, 6:e1000097.

14. White R, Perry KRW: Chlamydia trachomatis Nucleic Acid Amplification Tests (NAATs): Review of evaluation literature. London: Health Protection Agency; 2004. 
15. Higgins JPT, Thompson SG, Deeks JJ, Altman DG: Measuring inconsistency in meta-analyses. BMJ 2003, 327:557-560.

16. Hocking JS, Willis J, Tabrizi S, Fairley CK, Garland SM, Hellard M: A chlamydia prevalence survey of young women living in Melbourne, Victoria. Sex Health 2006, 3:235-240.

17. Debattista J, Lines D, James M, Patten J: Early detection of Chlamydia trachomatis in university residential colleges. Venereol Interdiscipl Int I Sex Health 1999, 12:35-36.

18. Debattista J, Martin P, Jamieson J, Crane K, Dolton I, Russell-Hall S, DeSilva J, Hargrave R, Robinson T, Ryan N, Mortlock M: Detection of Chlamydia trachomatis in an Australian high school student population. Sex Transm Infect 2002, 78:194-197.

19. Bowden FJ, O'Keefe EJ, Primrose R, Currie MJ: Sexually transmitted infections, blood-borne viruses and risk behaviour in an Australian senior high school population-the SHLiRP study. Sex Health 2005, 2:229-236.

20. Davis B, Schmidt M, O'Keefe E, Currie M, Baynes A, Bavinton T, McNiven M, Bowden F: 'Stamp Out Chlamydia' project - Bringing chlamydia screening to tertiary students in the Australian Capital Territory. Sex Health 2007, 4:287

21. Gold J, Hocking J, Hellard M: The feasibility of recruiting young men in rural areas from community football clubs for STI screening. Aust N Z J Public Health 2007, 31:243-246.

22. Wade AJ, Hocking JS, Hellard ME: Chlamydia trachomatis prevalence in heterosexual men in Melbourne: a community-based study. Sex Health 2007, 4:137-138.

23. Buhrer-Skinner M, Muller R, Menon A, Gordon R: Novel approach to an effective community-based chlamydia screening program within the routine operation of a primary healthcare service. Sex Health 2009, 6:51-56.

24. Kong FYS, Hocking JS, Link CK, Chen MY, Hellard ME: Sex and sport: chlamydia screening in rural sporting clubs. BMC Infect Dis 2009, 9:5.

25. Kong FYS, Hocking JS, Link CK, Chen MYC, Hellard ME: Sex and sport: sexual risk behaviour in young people in rural and regional Victoria. Sex Health 2010, 7:205-211.

26. Sacks-Davis R, Gold J, Aitken CK, Hellard ME: Home-based chlamydia testing of young people attending a music festival-who will pee and post? BMC Public Health 2010, 10:376.

27. Davies SC, Karagiannis T, Headon V, Wiig R, Duffy J: Prevalence of genital chlamydial infection among a community sample of young international backpackers in Sydney, Australia. Int J STD AIDS 2011, 22:160-164.

28. Heal C, Jones B, Veitch C, Lamb S, Hodgens S, Browning S, Butler H, Carey M: Screening for chlamydia in general practice. Aust Fam Physician 2002, 31:779-782

29. Chiang DTW, Tan ElL, Baldam A: Incidence of chlamydia infection among asymptomatic women presented for routine Papanicolaou smear: experience in South-Western Victoria. Australia. Rural Remote Health 2006, 6:633.

30. Toyne H, Glasgow N, McGuiness C, Bowden FJ, Currie MJ: Screening for chlamydia with the Pap test. Aust Fam Physician 2006, 35:743-744.

31. Bowden FJ, Currie MJ, Toyne H, McGuiness C, Lim LL, Butler JR, Glasgow NJ: Screening for Chlamydia trachomatis at the time of routine Pap smear in general practice: a cluster randomised controlled trial. Med J Aust 2008, 188:76-80.

32. Hince D, Brett T, Mak D, Bulsara M, Moorhead R, Arnold-Reed D: Opportunistic screening for chlamydia in young men. Aust Fam Physician 2009, 38:734-737.

33. Bilardi JE, Fairley CK, Temple-Smith MJ, Pirotta MV, McNamee KM, Bourke S, Gurrin LC, Hellard M, Sanci LA, Wills MJ, Walker J, Chen MY, Hocking JS: Incentive payments to general practitioners aimed at increasing opportunistic testing of young women for chlamydia: a pilot cluster randomised controlled trial. BMC Public Health 2010, 10:70

34. Walker J, Fairley CK, Bradshaw CS, Tabrizi SN, Chen MY, Twin J, Taylor N, Donovan B, Kaldor JK, McNamee K, Urban E, Walker S, Currie M, Birden H, Bowden FJ, Gunn J, Pirotta M, Gurrin LC, Harindra V, Garland SM, Hocking JS: The difference in determinants of Chlamydia trachomatis and Mycoplasma genitalium in a sample of young Australian women. BMC Infect Dis 2011, 11:35.

35. Bowden FJ: Reappraising the value of urine leukocyte esterase testing in the age of nucleic acid amplification. Sex Transm Dis 1998, 25:322-326.

36. Donovan B: Rising prevalence of genital Chlamydia trachomatis infection in heterosexual patients at the Sydney Sexual Health Centre, 1994 to 2000. Commun Dis Intell 2002, 26:51-55.
37. Williams H, Tabrizi SN, Lee W, Kovacs GT, Garland S: Adolescence and other risk factors for Chlamydia trachomatis genitourinary infection in women in Melbourne, Australia. Sex Transm Infect 2003, 79:31-34.

38. Hocking J, Fairley CK: Do the characteristics of sexual health centre clients predict chlamydia infection sufficiently strongly to allow selective screening? Sex Health 2005, 2:185-192.

39. Hocking J, Fairley CK: Associations between condom use and rectal or urethral chlamydia infection in men. Sex Transm Dis 2006, 33:256-258.

40. Bateson DJ, Weisberg E, Lota H: Chlamydia trachomatis infection in the family planning clinical setting across New South Wales. Sex Health 2006, 3:15-20.

41. Brandenburger Y, Currie MJ, Bowden FJ: Factors prompting men subsequently diagnosed with chlamydia to use a sexual health service. Sex Health 2007, 4:77-78.

42. Mclver CJ, Rismanto N, Smith C, Naing ZW, Rayner B, Lusk MJ, Konecny P, White PA, Rawlinson WD: Multiplex PCR testing detection of higher-thanexpected rates of cervical mycoplasma, ureaplasma, and trichomonas and viral agent infections in sexually active australian women. $J$ Clin Microbiol 2009, 47:1358-1363.

43. O'Rourke KM, Fairley CK, Samaranayake A, Collignon P, Hocking JS: Trends in chlamydia positivity over time among women in Melbourne Australia, 2003 to 2007. Sex Transm Dis 2009, 36:763-767.

44. Franklin N, O'Connor CC, Shaw M, Guy R, Grulich A, Fairley CK, Chen MY, Hellard M, Dickson B, Marshall L, Donovan B: Chlamydia at an inner metropolitan sexual health service in Sydney, NSW: Australian Collaboration for Chlamydia Enhanced Sentinel Surveillance (ACCESS) Project. Sex Health 2010, 7:478-483.

45. Goller JL, Guy RJ, Gold J, Lim MSC, El-Hayek C, Stoove MA, Bergeri I, Fairley $C K$, Leslie DE, Clift P, White B, Hellard ME: Establishing a linked sentinel surveillance system for blood-borne viruses and sexually transmissible infections: methods, system attributes and early findings. Sex Health 2010, 7:425-433

46. Guy R, Wand H, Franklin N, Fairley CK, Chen MY, O'Connor CC, Marshall L, Grulich AE, Kaldor JM, Hellard M, Donovan B: Re-testing for chlamydia at sexual health services in Australia, 2004-08. Sex Health 2011, 8:242-247.

47. McKechnie ML, Hillman RJ, Jones R, Lowe PC, Couldwel DL, Davies SC, King F, Kong FR, Gilbert GL: The prevalence of urogenital micro-organisms detected by a multiplex PCR-reverse line blot assay in women attending three sexual health clinics in Sydney, Australia. J Med Microbiol 2011, 60:1010-1016

48. Vodstrcil LA, Fairley CK, Fehler G, Leslie D, Walker J, Bradshaw CS, Hocking JS: Trends in chlamydia and gonorrhea positivity among heterosexual men and men who have sex with men attending a large urban sexual health service in Australia, 2002-2009. BMC Infect Dis 2011, 11:158.

49. Rosenthal DA, Fairley CK, Garland SM, Tebrizi SN, Raynor K, Edwards C, Gregson S, Walsh J: Homeless young people: an important risk group for sexually transmitted infections. Med J Aust 2000, 172:244.

50. Cole R, Jasiak S: What do you get when you fall in love?: Warehouse Youth Health Centre chlamydia audit. Aust J Adv Nurs 2004, 22:19-24.

51. Jones S, Barker $\mathrm{S}$, Athan E, Graves S: The tip of the iceberg: opportunistic screening for Chlamydia trachomatis in asymptomatic patients attending a young people's health clinic reveals a high prevalence-a pilot study. Sex Health 2004, 1:115-119.

52. Kang M, Rochford A, Johnston V, Jackson J, Freedman E, Brown K, Mindel A: Prevalence of Chlamydia trachomatis infection among 'high risk' young people in New South Wales. Sex Health 2006, 3:253-254.

53. Gilbert J, Ryder N, McNulty AM: Drop-in versus appointments for youth are more 'at risk' youth attending the satellite sexual health cinic since it became a drop in only clinic? Sex Health 2009, 6:352.

54. Debattista J, Gazzard CM, Wood RN, Allan JA, Allan JM, Scarman A, Mortlock $M$, Timms P, Knox CL: Interaction of microbiology and pathology in women undergoing investigations for infertility. Infect Dis Obstet Gynecol 2004, 12:135-145.

55. Petersen RW, Tabrizi SN, Garland S, Quinlivan JA: Prevalence of Chlamydia trachomatis in a public colposcopy clinic population. Sex Health 2007, 4:133-136.

56. Dykstra CA, Flexman J, Fatovich D, McCloskey JC: Royal Perth Hospital emergency department screening project for Chlamydia trachomatis. Sex Health 2008, 5:382

57. Bowden FJ, Paterson BA, Tabrizi SN, Fairley CK, Garland SM: Using selfadministered tampons to diagnose STDs. AIDS Patient Care STDS 1998 12:29-32. 
58. Garland SM, Tabrizi S, Hallo J, Chen S: Assessment of Chlamydia trachomatis prevalence by PCR and LCR in women presenting for termination of pregnancy. Sex Transm Infect 2000, 76:173-176.

59. Garrow SC, Smith DW, Harnett GB: The diagnosis of chlamydia, gonorrhoea, and trichomonas infections by self obtained low vaginal swabs, in remote northern Australian clinical practice. Sex Transm Infect 2002, 78:278-281.

60. Quinlivan JA, Evans SF: The impact of continuing illegal drug use on teenage pregnancy outcomes - a prospective cohort study. BJOG 2002, 109:1148-1153.

61. Quinlivan JA, Petersen RW, Davy M, Evans SF: Abnormal pap smears in teenage mothers and the association with domestic violence, homelessness, and chlamydia. J Low Genit Tract Dis 2004, 8:112-117.

62. Cheney K, Chen MY, Donovan B: Chlamydia trachomatis among antenatal women in Sydney. Aust N Z J Public Health 2006, 30:85-87.

63. Panaretto KS, Lee HM, Mitchell MR, Larkins SL, Manessis V, Buettner PG, Watson D: Prevalence of sexually transmitted infections in pregnant urban Aboriginal and Torres Strait Islander women in northern Australia. Aust N Z J Obstet Gynaecol 2006, 46:217-224.

64. Lenton JA, Freedman E, Hoskin K, Knight V, Turley D, Balding B, Kennedy C, Chen MY, McNulty A: Chlamydia trachomatis infection among antenatal women in remote far west New South Wales, Australia. Sex Health 2007, 4:139-140.

65. Cheney K, Wray L: Chlamydia and associated factors in an under 20s antenatal population. Aust N Z J Obstet Gynaecol 2008, 48:40-43.

66. Combs BG, Kwan KSH, Giele CM, Mak DB: Audit of antenatal testing of sexually transmissible infections and blood borne viruses at Western Australian hospitals. Sex Health 2008, 5:390

67. Chen MY, Fairley CK, De Guingand D, Hocking JS, Tabrizi S, Wallace EM, Grover S, Gurrin L, Carter R, Pirotta M, Garland S: Screening pregnant women for chlamydia: what are the predictors of infection? Sex Transm Infect 2009, 85:31-35.

68. Ward J, Goller J, Bergeri I, Kong F, Franklin N, Sullivan L, Dimech W, Kaldor JM, Donovan B, Hellard M, Guy R: Understanding epidemiology of chlamydia related to Aboriginal and Torres Strait Islander people: first results from the ACCESS network project. Sydney: Australasian Sexual Health Conference; 2010.

69. Miller PJ, Torzillo PJ, Hateley W: Impact of improved diagnosis and treatment on prevalence of gonorrhoea and chlamydial infection in remote Aboriginal communities on Anagu Pitjantjatjara Lands. Med J Aust 1999, 170:429-432.

70. Huang R-L, Torzillo PJ, Hammond VA, Coulter ST, Kirby AC: Epidemiology of sexually transmitted infections on the Anangu Pitjantjatjara Yankunytjatjara Lands: results of a comprehensive control program. Med J Aust 2008, 189:442-445

71. Knox J, Tabrizi SN, Miller P, Petoumenos K, Law M, Chen S, Garland SM: Evaluation of self-collected samples in contrast to practitioner-collected samples for detection of Chlamydia trachomatis, Neisseria gonorrhoeae, and Trichomonas vaginalis by polymerase chain reaction among women living in remote areas. Sex Transm Dis 2002, 29:647-654.

72. Miller GC, McDermott R, McCulloch B, Fairley CK, Muller R: Predictors of the prevalence of bacterial STI among young disadvantaged Indigenous people in north Queensland, Australia. Sex Transm Infect 2003, 79:332-335.

73. Latif A, Smith K: STI screening conducted in NT Department of Health and Community Services and Community Controlled Health Services in Central Australia in 2004. NT Dis Control Bull 2004, 11:18-20.

74. Panaretto KS, Dallachy D, Manessis V, Larkins S, Tabrizi S, Upcroft J, Garland S: Cervical smear participation and prevalence of sexually transmitted infections in women attending a community-controlled Indigenous health service in north Queensland. Aust N Z J Public Health 2006, 30:171-176.

75. Spurling GKP, Hayman NE, Cooney AL: Adult health checks for Indigenous Australians: the first year's experience from the Inala Indigenous Health Service. Med J Aust 2009, 190:562-564.

76. Fairbairn AP, Tyler H, Su J-Y, Tilley EL: Risk factors and associations for the diagnosis of sexually transmitted infections in Aboriginal women presenting to the Alice Springs Hospital emergency department. Emerg Med Australas 2010, 22:216-223.

77. Goller J, Ward J, Saunders M, Bergeri I, Kaldor J, Williams S, Waples-Crowe P, Moore E, Hunt J, Scrimgeour D, Boyle D, Couzos S, Donovan B, Hellard M: A snapshot of chlamydia testing and positivity in eight Aboriginal Community Controlled Health Services: Useful information for local quality improvement. Sydney: Australasian Sexual Health Conference; 2010.
78. Templeton DJ, Tyson BA, Meharg JP, Habgood KE, Bullen PM, Malek S, McLean R: Aboriginal health worker screening for sexually transmissible infections and blood-borne viruses in a rural Australian juvenile correctional facility. Sex Health 2010, 7:44-48.

79. Debattista J, Dwyer J, Orth D, Lister G, Patten J: Community screening for Neisseria gonorrhoeae and Chlamydia trachomatis among patrons of sexon-premises venues: two years later. Venereol Interdiscipl Int I Sex Health 2000, 13:105-109.

80. Debattista J, Clementson C, Mason D, Dwyer J, Argent S, Woodward C, Dean J, Buks L, Copley M, Hinwood G, Benfield C, Walton P: Screening for Neisseria gonorrhoeae and Chlamydia trachomatis at entertainment venues among men who have sex with men. Sex Transm Dis 2002, 29:216-221.

81. Lister NA, Smith A, Tabrizi S, Hayes P, Medland NA, Garland S, Fairley CK: Screening for Neisseria gonorrhoeae and Chlamydia trachomatis in men who have sex with men at male-only saunas. Sex Transm Dis 2003, 30:886-889.

82. Lister NA, Smith A, Read T, Fairley CK: Testing men who have sex with men for Neisseria gonorrhoeae and Chlamydia trachomatis prior to the introduction of guidelines at an STD clinic in Melbourne. Sex Health 2004, 1:47-50.

83. Lister NA, Smith A, Tabrizi SN, Garland S, Hayes P, Fairley CK: Comprehensive clinical care on-site in men-only saunas: confidential STI/ HIV screening outreach clinic. Int J STD AIDS 2005, 16:794-798.

84. Lister NA, Smith A, Fairley CK: Introduction of screening guidelines for men who have sex with men at an STD clinic, the Melbourne Sexual Health Centre, Australia. Sex Health 2005, 2:241-244.

85. Currie MJ, Martin SJ, Soo TM, Bowden FJ: Screening for chlamydia and gonorrhoea in men who have sex with men in clinical and non-clinical settings. Sex Health 2006, 3:123-126.

86. Hamlyn E, McAllister J, Winston A, Sinclair B, Amin J, Carr A, Cooper DA: Is screening for sexually transmitted infections in men who have sex with men who receive non-occupational HIV post-exposure prophylaxis worthwhile? Sex Transm Dis 2006, 82:21-23.

87. Jin F, Prestage GP, Zablotska I, Rawstorne P, Kippax SC, Donovan B, Cunningham PH, Templeton DJ, Kaldor JM, Grulich AE: High rates of sexually transmitted infections in HIV positive homosexual men: data from two community based cohorts. Sex Transm Infect 2007, 83:397-399.

88. Templeton DJ, Jin F, Imrie J, Prestage GP, Donovan B, Cunningham PH, Kaldor JM, Kippax S, Grulich AE: Prevalence, incidence and risk factors for pharyngeal chlamydia in the community based Health in Men (HIM) cohort of homosexual men in Sydney, Australia. Sex Transm Infect 2008, 84:361-363.

89. McNulty A, Teh MF, Freedman E: Patient delivered partner therapy for chlamydial infection-what would be missed? Sex Transm Dis 2008, 35:834-836.

90. Teague R, Mijch A, Fairley CK, Sidat M, Watson K, Boyd K, Chen MY: Testing rates for sexually transmitted infections among HIV-infected men who have sex with men attending two different HIV services. Int J STD AIDS 2008, 19:200-202.

91. Guy RJ, Wand H, Franklin N, Fairley CK, Chen MY, O'Connor CC, Marshall L Grulich AE, Kaldor JM, Hellard ME, Donovan B: Chlamydia trends in men who have sex with men attending sexual health services in Australia, 2004-2008. Sex Transm Dis 2011, 38:339-346.

92. Morton AN, Wakefield T, Tabrizi SN, Garland SM, Fairley CK: An outreach programme for sexually transmitted infection screening in street sex workers using self-administered samples. Int J STD AIDS 1999, 10:741-743.

93. Morton AN, Tabrizi SN, Garland SM, Lee PJ, Reid PE, Fairley CK: Will the legalisation of street sex work improve health? Sex Transm Infect 2002, 78:309.

94. O'Connor JL, Harcourt C, Wand H, Egger S, Fairley CK, Kaldor JM, Marshall L, Bates $J$, Donovan B: The sex industry in Perth before decriminalisation. Sex Health 2008, 5:384.

95. Mak DB, Johnson GH, Marshall $\sqcup$, Mein JK: Control of genital chlamydial infection in the Kimberley region of Western Australia. Med J Aust 2004, $180: 45$.

96. Watkins RE, Mak DB, Connelly C: Testing for sexually transmitted infections and blood borne viruses on admission to Western Australian prisons. BMC Public Health 2009, 9:385.

97. Bradshaw CS, Pierce LI, Tabrizi SN, Fairley CK, Garland SM: Screening injecting drug users for sexually transmitted infections and blood borne 
viruses using street outreach and self collected sampling. Sex Transm Infect 2005, 81:53-58.

98. Macleod J, Salisbury C, Low N, McCarthy A, Sterne JAC, Holloway A, Patel R, Sanford E, Morcom A, Horner P, Smith GD, Skidmore S, Herring A, Caul O, Hobbs FDR, Egger M: Coverage and uptake of systematic postal screening for genital Chlamydia trachomatis and prevalence of infection in the United Kingdom general population: cross sectional study. BMJ 2005, 330:940-942.

99. Fenton KA, Korovessis C, Johnson AM, McCadden A, McManus S, Wellings K, Mercer CH, Carder C, Copas AJ, Nanchahal K, Macdowall W, Ridgway G, Field J, Erens B: Sexual behaviour in Britain: reported sexually transmitted infections and prevalent genital Chlamydia trachomatis infection. Lancet 1851, 2001:358.

100. Adams EJ, Charlett A, Edmunds WJ, Hughes G: Chlamydia trachomatis in the United Kingdom: a systematic review and analysis of prevalence studies. Sex Transm Infect 2004, 80:354-362.

101. Johnson AM, Mercer CH, Erens B, Copas AJ, McManus S, Wellings K, Fenton KA, Korovessis C, Macdowall W, Nanchahal K, Purdon S, Field J: Sexual behaviour in Britain: partnerships, practices, and HIV risk behaviours. Lancet 2001, 358:1835-1842.

102. Rissel CE, Richters J, Grulich AE, Visser ROd, Smith AMA: Sex in Australia: First experiences of vaginal intercourse and oral sex among a representative sample of adults. Aust N Z J Public Health 2003, 27:131-137.

103. Smith AMA, Rissel CE, Richters J, Grulich AE, de Visser RO: Sex in Australia: The rationale and methods of the Australian study of health and relationships. Aust N Z J Public Health 2003, 27:106-117.

104. Morgan J, Haar J: Who goes to a sexual health clinic? Gender differences in service utilisation. N Z Med J 2008, 121:44-49.

105. Centers for Disease Control and Prevention: Sexually Transmitted Disease Surveillance 2010. Atlanta: U.S. Department of Health and Human Services; 2011.

106. Datta SD, Sternberg M, Johnson RE, Berman S, Papp JR, McQuillan G, Weinstock H: Gonorrhea and Chlamydia in the United States among Persons 14 to 39 Years of Age, 1999 to 2002. Ann Intern Med 2007, 147:89-96.

107. Annan NT, Sullivan AK, Nori A, Naydenova P, Alexander S, McKenna A, Azadian B, Mandalia S, Rossi M, Ward H, Nwokolo N: Rectal chlamydia - a reservoir of undiagnosed infection in men who have sex with men. Sex Transm Infect 2009, 85:176-179.

108. Kent CK, Chaw JK, Wong W, Liska S, Gibson S, Hubbard G, Klausner JD: Prevalence of rectal, urethral, and pharyngeal chlamydia and gonorrhea detected in 2 clinical settings among men who have sex with men: San Francisco, California, 2003. Clin Infect Dis 2005, 41:67-74.

109. STIs in Gay Men Action Group (STIGMA): Sexually transmitted infection testing guidelines for men who have sex with men. Sydney: STIs in Gay Men Action Group (STIGMA); 2010.

110. Department of Health and Ageing: Second National Sexually Transmissible Infections Strategy: 2010-2013. Barton: Commonwealth of Australia; 2010

111. Liaw S-T, Boyle DIR: Primary care informatics and integrated care. Stud Health Technol Inform 2010, 151:255-268.

112. Mak DB, Watkins RE: Improving the accuracy of Aboriginal and nonAboriginal disease notification rates using data linkage. BMC Health Serv Res 2008, 8:118.

doi:10.1186/1471-2334-12-113

Cite this article as: Lewis et al:: The prevalence of Chlamydia trachomatis infection in Australia: a systematic review and meta-analysis. BMC Infectious Diseases 2012 12:113.

\section{Submit your next manuscript to BioMed Central and take full advantage of:}

- Convenient online submission

- Thorough peer review

- No space constraints or color figure charges

- Immediate publication on acceptance

- Inclusion in PubMed, CAS, Scopus and Google Scholar

- Research which is freely available for redistribution

Submit your manuscript at www.biomedcentral.com/submit
Biomed Central 